Portland State University

PDXScholar

Anthropology Faculty Publications and

Presentations

Anthropology

Spring 2016

\title{
Chinookan Villages of the Lower Columbia
}

Henry B. Zenk

Portland State University

Yvonne P. Hajda

Robert T. Boyd

Portland State University, rtboyd@pdx.edu

Follow this and additional works at: https://pdxscholar.library.pdx.edu/anth_fac

Part of the Social and Cultural Anthropology Commons

Let us know how access to this document benefits you.

\section{Citation Details}

Zenk H., Hajda, Y., and Boyd, R. (2016). Chinookan Villages of the Lower Columbia. Oregon Historical Quarterly, Vol. 117, No. 1, pp. 6-37.

This Article is brought to you for free and open access. It has been accepted for inclusion in Anthropology Faculty Publications and Presentations by an authorized administrator of PDXScholar. Please contact us if we can make this document more accessible: pdxscholar@pdx.edu. 


\section{Chinookan Villages of the Lower Columbia}

\section{HENRY ZENK, YVONNE HAJDA, AND ROBERT BOYD}

VILLAGES WERE THE CENTER of Chinookan life, filling the role that tribes did for Native people in other parts of North America. Every village of any size or significance had a recognized leader or chief, and constituted a named local group with which its members identified themselves. Although the villages themselves are long vanished, early travelers, missionaries, and settlers have left us eyewitness accounts of what some were like. The names and approximate locations of many more can be reconstructed from historical sources and information shared by later generations of lower Columbia River Native people.

As contributors to the recently published Chinookan Peoples of the Lower Columbia, one of our goals was to recreate, as best as possible given the available data, a comprehensive list of Chinookan villages on the lower Columbia River (Astoria to Cascade Locks) as they existed in the first half of the nineteenth century. ${ }^{1}$ The complete village list (available only online) names over eighty villages and larger groupings, representing a population of at least 15,000 people speaking Chinookan languages, and probably many more. ${ }^{2}$

The history and culture of these people is largely unknown to most Oregonians, yet recent and ongoing research by both academics and tribal descendants has uncovered a good deal of new information, supplementing that passed on by previous generations of scholars and their tribal consultants. The traditional culture of the Chinookan peoples constituted a successful way of living on the lower Columbia that developed over many millennia. It is the ancestral culture of the Chinook Indian Nation (embracing the Clatsop and Kathlamet Chinooks of Oregon and the Lower Chinook, Wahkiakum, and Willapa Chinooks of Washington) and members of other tribal communities, as well as of fellow citizens who have Chinookan ancestry but belong to no tribal community, and it is part of our shared heritage as citizens of Oregon and Washington. 


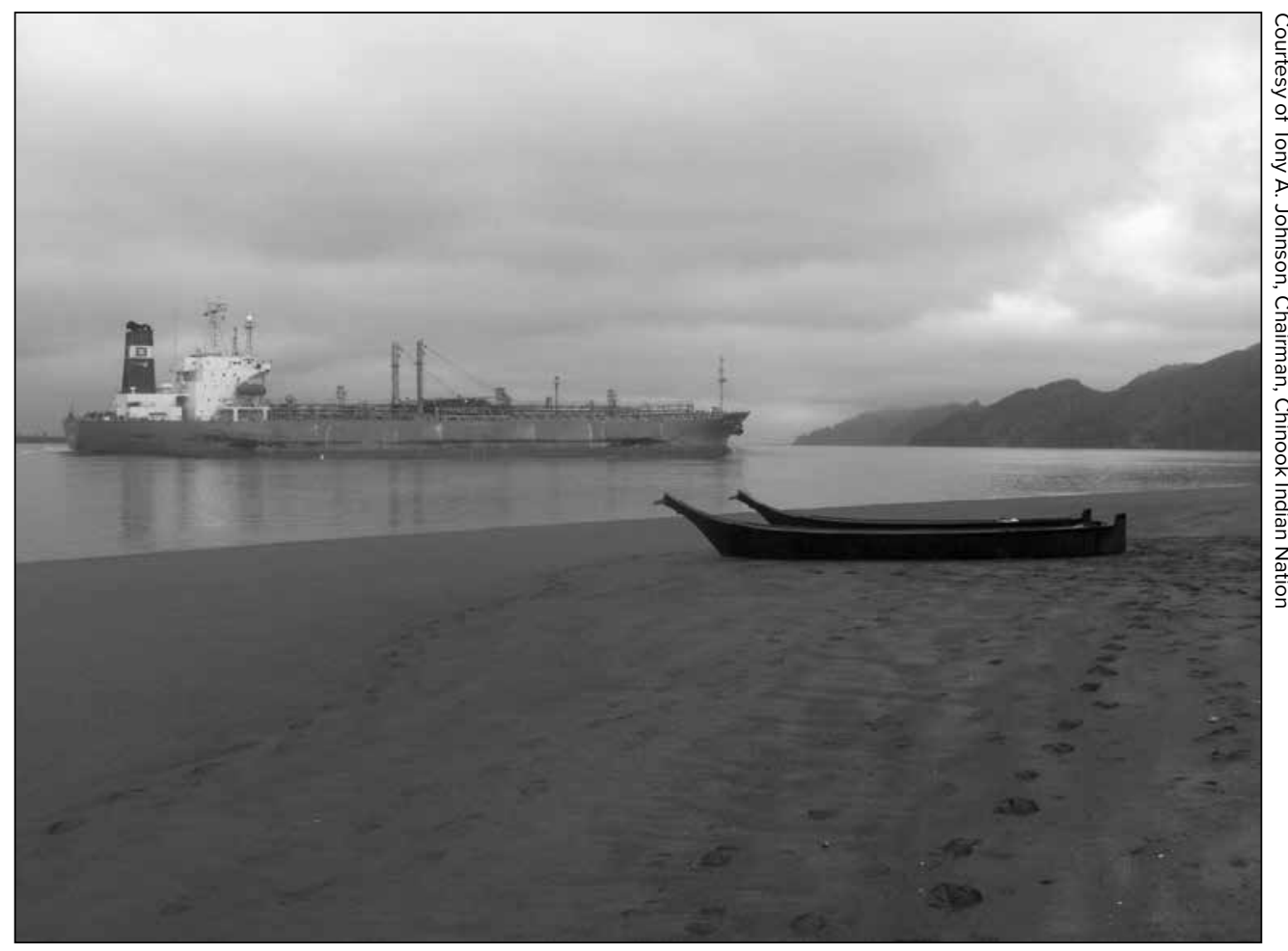

$\mathbf{k}^{\text {ha }}$ chinuk-k hanim miłayt $\mathbf{k}^{\text {hapa }}$ ukuk hayásh-tsəqw (iyagaytł imał) translates to 'Chinook Canoes Still Travel the Great (Columbia) River.' These canoes are historically known as "Chinook" and are featured on the website of the contemporary Chinook Nation, www. chinooknation.org. Tony A. Johnson, Chairman of the Chinook Indian Nation, composed the legend in Chinuk Wawa, using a practical alphabet developed with Henry Zenk. hayásh-tsəqw', meaning literally, "Great Water," names the Columbia River. In the original Chinookan languages of the Chinook Nation, the river is imał or iyagaytł imał, both translating to 'Great Water.'

The complete Chinookan Peoples of the Lower Columbia (hereafter, CPLC) village list was too long and too packed with detail to fit comfortably in the print volume, so an editorial decision was made to place it online. ${ }^{3}$ To make the CPLC village list more widely known and accessible to the Northwest reading public, we have prepared this guide for the Oregon Historical Quarterly. Here we will summarize and describe the list in general terms and present some illustrative examples of the complexities it contains. Some of the sources we draw on have never before been utilized by scholars; and we offer new interpretations of a number of issues left unresolved by previous compilers. 


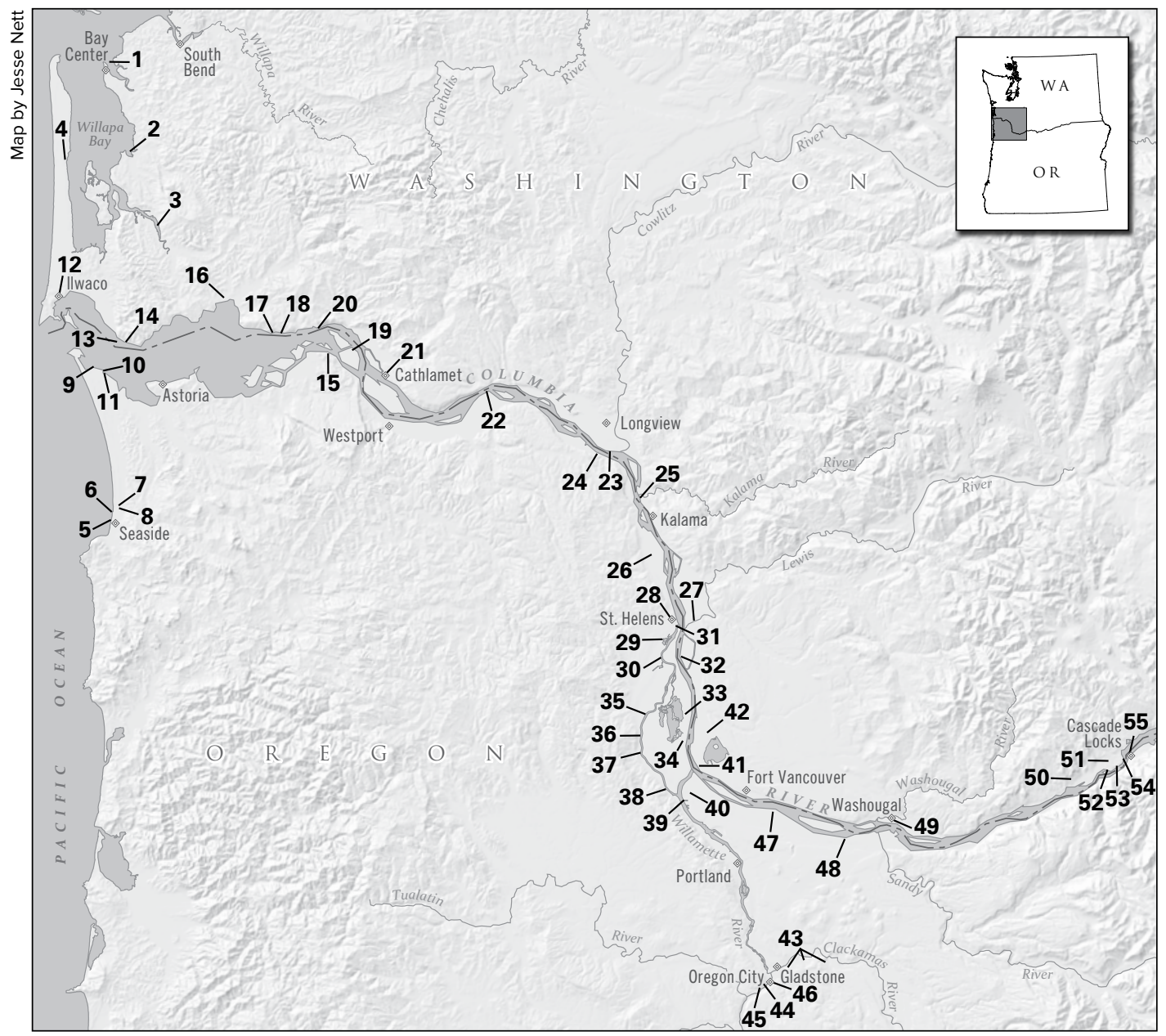

FIGURE 1: This map and list of best-documented Lower Columbia Chinookan villages (facing page) are modified somewhat from those appearing in Chinookan Peoples of the Lower Columbia. Besides adding nontechnical spellings, they also reflect results of ongoing research incorporated into the online versions, which, unlike the print version, are subject to periodic revision. The online version of Chinookan Peoples of the Lower Columbia can be found at http://www.pdx.edu/anthropology/ chinookan-peoples-supplemental-materials. 
Willapa Bay (mixed Chinookan-Salishan)

1. X'pílqs Tlpilks

2. nímax ${ }^{w}$ Nemah

3. gitłálilam Gitlalilam

4. tiápšuyi Tiyapshuyi

\section{Clatsop}

5. nakut'át Nakutat

6. Necanicum (Lewis and Clark) (nikánikəm)

7. niáxaqši Neacoxi

8. niák'iwanqi Niyakiwanki

9. tłác'əp Clatsop (tiák'ilakix

Tiyakilakikh)

10. K'unúpi Kunupi

11. naiáaqštawi Naya-akshtawi

\section{Chinook}

12. wiitčutk Witchutk

13. c'inúk (činúk $\left.{ }^{w}\right)$ Chinook

14. qíq'ayaqilxam Kikayakilkham (Salish k'acámc' Kwatsamats)

Downstreamers (itgígwalatkš Itkigwalatksh)

15. gałámat Cathlamet (Kathlamet)

16. wáqaiqam Wahkiakum

17. čak'wayálxam Chakwayalkham

18. đálgak Tlalgak

19. tənəs-íliri Tenasillahe (Chinuk Wawa name)

20. gađiášgənəmaxix

Gatliyashganamakhikh

21. gatia?išádxix Gatliya-ishalkhikh

22. giłáxaniak Kaniyak

23. šiámištix Shiyamishtikh (qašiámištix Kashiyamishtikh)

24. kłágulaq Ktlagulak

\section{Classification Uncertain}

25. gaqák'alama Kalama

26. Cathlahaws (Lewis and Clark)

\section{Wapato Valley}

27. gáqap'u^x Cathlapotle

28. náiaguguix Nayaguguwikh

29. đáqst'ax Tlakstakh

30. gałáq'map

31. sqápus Scappoose

32. namúitk Namuwitk

33. Clannahquah (Lewis and Clark)

34. máqnumax Multnomah

35. Cathlanaminimin (Lewis and Clark)

36. Claninata (Lewis and Clark)

37. gałánaqwaix Gatlanakwaikh

38. Cathlacommahtup (Lewis and Clark)

39. Nemalquinner (Lewis and Clark) (nimáqx ${ }^{w}$ inix) (?))

40. gađáwakšin Gatlawakshin

41. gađák'anasisi (wák'anasisı) Wakanasisi

42. Shoto (Lewis and Clark)

Those of Clackamas River (giłáq'imaš)

43. đáq'imaš Clackamas

\section{Willamette Falls}

44. đáwiwala, (gała)wálamt Willamette

45. čaká'wa Chakawa (Molala name)

46. Cushooks (Lewis and Clark) (k'ášxəkš (ix) (?))

Upstreamers (šáxlatkš Shakhlatksh)

47. Neerchokioo (Lewis and Clark) (gaqađála Watlala)

48. Nechakolee, Nechercokee [sic] (Lewis and Clark) (ničáq $\left.{ }^{w} l i\right)$ (?))

49. gađawašúx ${ }^{w a / \text { Washougal }}$

50, 51, 54. gađađála (đađála, wałála ) Watlala

52. qixayagílxam Kikhayagilkham

53. sk'mániak Skamania

55. gaławáiaxix Gatlawayakhikh 


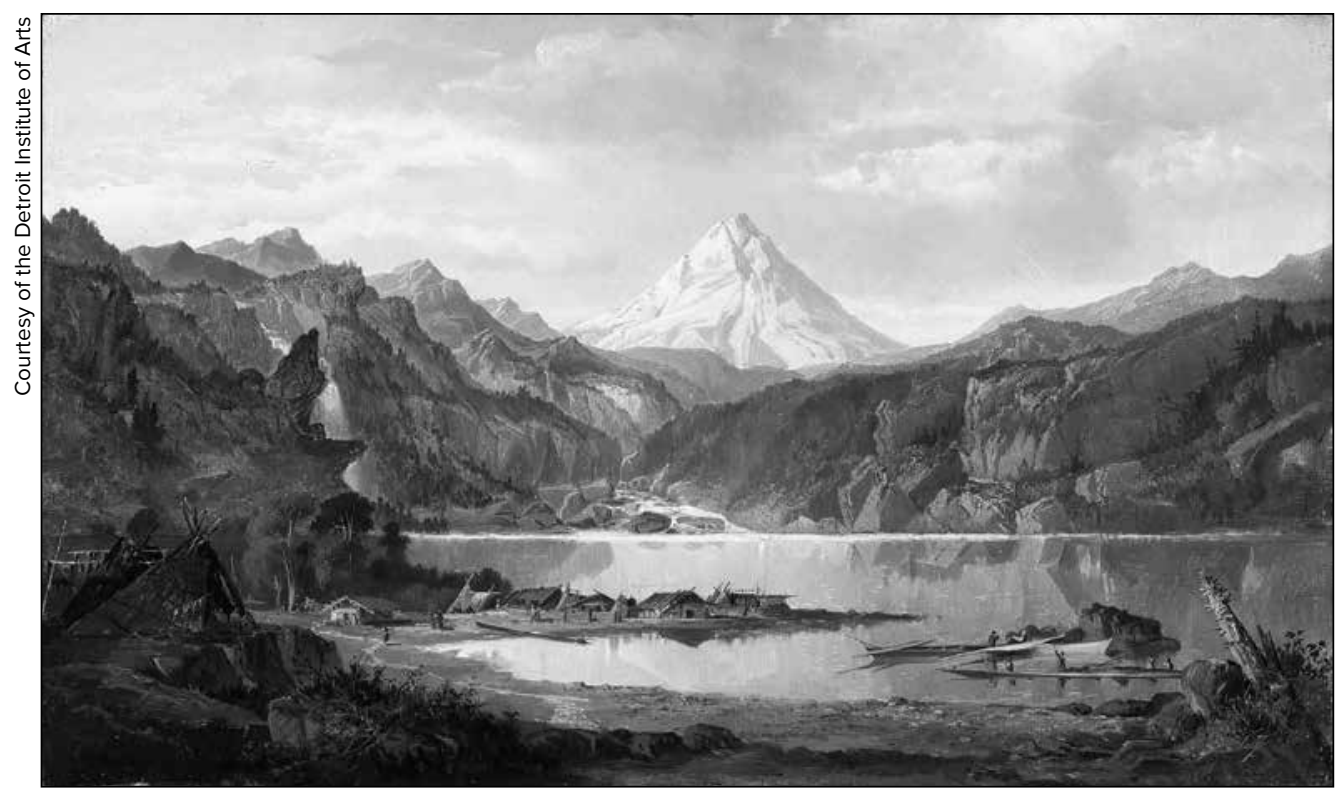

JOHN MIX STANLEY'S Mountain Landscape with Indians was painted in Detroit in about 1870. Stanley was in the Northwest in 1847-1848 and again in 1853. The painting may be modeled on earlier paintings lost in a fire, on field sketches, or even on an on-location daguerreotype. The exact location is uncertain, although certainly somewhere in the Columbia River Gorge. It is the only extant depiction of a Chinookan village and shows impressive detail, particularly in the different kinds of structures.

\section{CHINOOKAN LINGUISTIC AND ETHNIC DIVISIONS}

Chinookan languages were spoken in clusters of village dialects, stretching along the lower Columbia River from its mouth upriver to just above The Dalles and beyond its banks into the Willapa Bay region to the north and the Clatsop Plains and lower Willamette River regions to the south. The villages clustered about the mouth of Columbia River as well as Willapa Bay and Clatsop Plains spoke dialects of one language, called Lower Chinook. The dialects of villages from the upper reaches of the Columbia River estuary to The Dalles have usually been named Upper Chinook. More recently, the late Dell Hymes suggested the terms Kathlamet or Middle Chinook for the village dialects spoken from the Columbia River estuary upriver nearly to the Portland Basin. ${ }^{4}$ The village dialects of the Portland Basin (historically: the Wapato Valley) region were never adequately documented, leaving some uncertainty as to just how the Chinookan spoken downriver from there was related to the cluster of village provincialisms next upriver from 
the Portland Basin, taking in Willamette Falls, the lower Clackamas River, and the Cascades of the Columbia River. Villagers in these three regions spoke closely related dialects, which together with Wasco and Wishram farther to the east are usually referred to by the collective name Kiksht. Kiksht, in turn, is usually classified as an Upper Chinook dialect cluster. In Hymes's judgment, Kathlamet Chinook and Kiksht Chinook were different enough to be considered distinct languages. Very likely, they constituted opposite ends of a chain of dialects beginning with the westernmost dialects of Kathlamet, and extending upriver through the Wapato Valley all the way to the easternmost dialects of Kiksht. Any two immediately succeeding dialects in this chain would very likely have been fully mutually intelligible. Of all the many Chinookan provincialisms spoken in the early nineteenth century, only Wasco-Wishram Kiksht hangs on today, thanks in large measure to a language program and classes at Warm Springs Reservation, Oregon. ${ }^{5}$

Since CPLC's geographical coverage extends eastward only to The Cascades of the Columbia River, the CPLC village list excludes the easternmost Kiksht dialects, Wishram and Wasco. Our division of the resulting lower Columbia focal region into eight groupings or clusters of villages is based on a combination of linguistic, historical, and geographical considerations. Similar considerations underlie the previous most authoritative list of lower Columbia Chinookan villages, compiled by Michael Silverstein for volume 7 (The Northwest) of The Handbook of North American Indians (hereafter the Handbook). ${ }^{6}$ Based on linguistic affinity, Silverstein combines our Willapa Bay, Chinook, and Clatsop clusters into one: named Lower Chinook, for the Chinookan language spoken in those three groupings of villages. Our itgígwalatkš (Itkigwalatksh) 'downstreamers' cluster is nearly coterminous with the cluster he names Cathlamet (a historical synonym of Kathlamet). With some allowances for the two lists' non-coinciding eastern boundaries, he names our Wapato Valley cluster Multnomah (following Meriwether Lewis and William Clark, who named the Willamette River for its proximity to our village number 34; see figure 1); and he combines our Clackamas River and Willamette Falls clusters into one, designated Clackamas (the linguists' usual name for the Kiksht dialects of this general region). Our 'upstreamers' (šáxlatkš) cluster, centered on The Cascades of the Columbia River, appears in the separate list of Chinookan villages compiled by David and Kathrine French for volume 12 of the Handbook. ${ }^{7}$

The terms itgíg walatkš 'downstreamers' and šáxlatkš 'upstreamers' comprise a complementary pair. Their documentation as ethnic names highlights the fact that Chinookans usually expressed geographical orientation in relation to water, and frequently, using the languages' stock of complementary contrasts including the pairs 'upstream' and 'downstream', 'towards 
water' and 'away from water (inland)'. The term šáxlatkš ('upstreamers') for Cascades-region Chinookans seems to have been in general use all along the river. The Downstreamers/Kathlamet region of the river is less well known. Two later-day Kiksht speakers gave itgíg walatkš as a Chinookan name for the region; and two later-day Kathlamet speakers used "Kathlamet" (from the region's principal late-historical village, figure 1, village 15), also for the Chinookan spoken throughout the same region. ${ }^{8}$

The CPLC village list updates the earlier Handbook compilations, with revisions and expansions made possible by newly uncovered primary sources. It is worth noting that all these compilations are synthetic creations, drawing on both historical eyewitness accounts and the recollections of late-surviving speakers of lower Columbia indigenous languages, all interviewed at a time when the villages themselves were little more than fading memories. Only the later documentation from Chinookan speakers preserves the phonetic detail necessary for accurately representing how the names were pronounced in Chinookan. Where sufficient phonetic detail is available, the names appear italicized on our list, spelled in the Chinookan phonemic alphabet developed by linguists. ${ }^{9}$ To aid general readers, we have also provided non-technical respellings for each phonemically spelled name in the abbreviated village-list appearing in figure 1. The respellings in figure 1 rely on contemporary English geographic names where available (these appear in bold type); elsewhere, they show rough English-alphabet verisimilitudes of Chinookan phonemes, with the understanding that the vowels are to be pronounced as in Italian and Spanish and the consonants as in English. Names not supported by the phonetic detail necessary for phonemic respelling are cited directly from the journals of Lewis and Clark, which provide by far the most comprehensive contemporary record of lower Columbia villages. ${ }^{10}$

The resulting abbreviated list of fifty-five numbered villages represents but a small subset of the total number of Chinookan villages on record. Each was identified by visitors traveling the river when the village was still populated, and/or by two or more independent mentions in later sources, notably those citing the memories of Chinookan-speaking elders. In the CPLC online expanded version, each of these numbered villages is followed by a list of synonyms from historical and ethnographic sources, given in their original spellings. The online version also includes notes that give names of additional villages that do not meet the strict criteria reserved for numbered villages on our list, but that do appear in principal historical and ethnographic sources. In addition, the online list contains many footnoted 


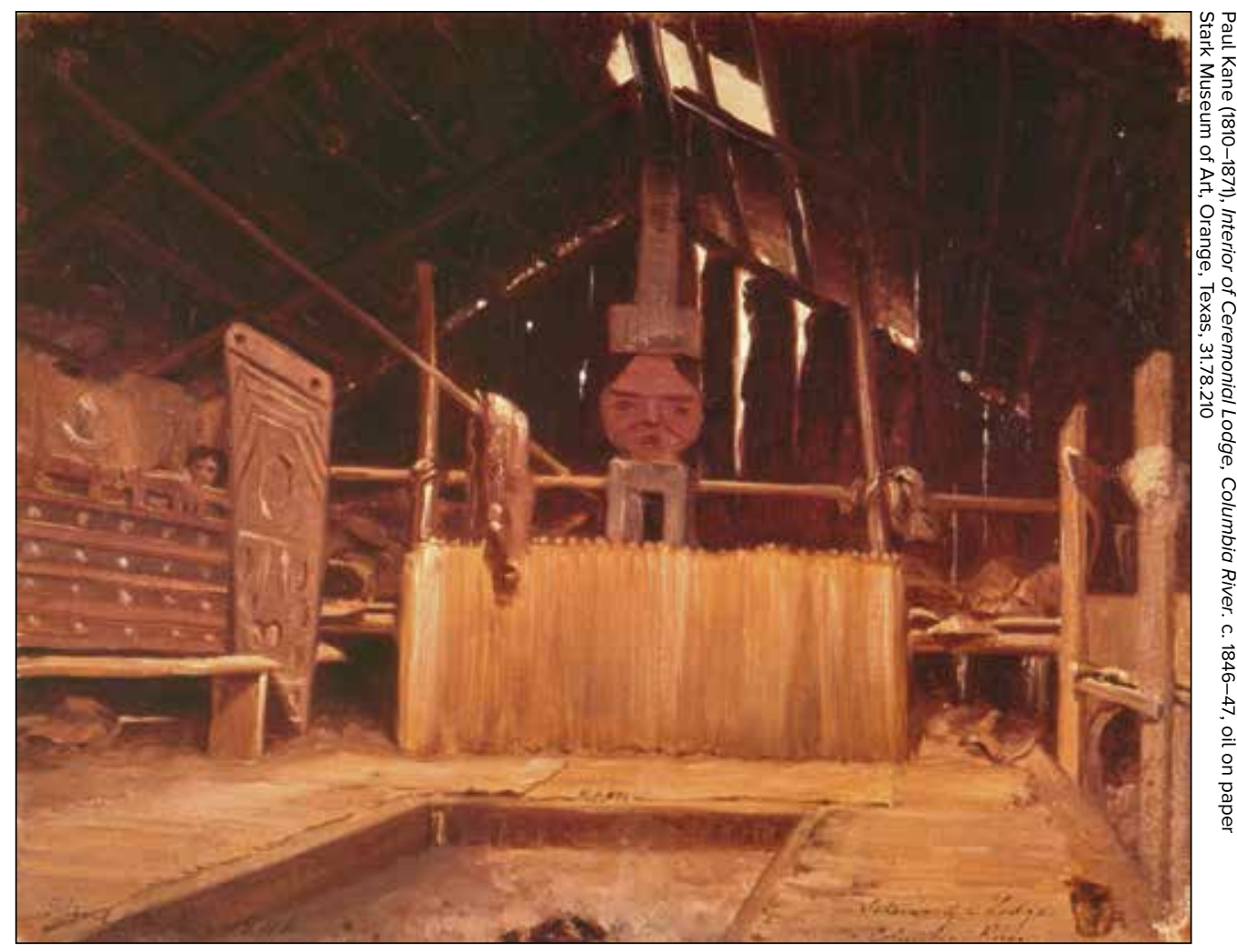

PAUL KANE'S PAINTING, Interior of Ceremonial Lodge, Columbia River, is generally assumed to be set somewhere near Fort Vancouver, Washington. Other than the reference in Kane's "Landscape Log" to "a Chinook lodge interior painted at Vancouver," there is no mention of this painting in his writings; nor is there a field sketch. Despite its sparse documentation, it contains impressive ethnographic detail. Note the anthropomorphic upright in the rear high-ranking section of the house and the screen before it. There is a carved spirit board to the left, and relief carvings on the raised sleeping berths along the house's side walls.

annotations, some addressing problematic identifications, others supplying supplementary historical and ethnographic detail. Readers interested in more detail are encouraged to consult the online list.

\section{THE EARLY NINETEENTH CENTURY CHINOOKAN VILLAGE UNIT}

Some of the most descriptive and revealing records of lower Columbia village life come from the eyewitness accounts of explorers, traders, missionaries, and settlers from the first half of the nineteenth century. Outsiders' descriptions of their initial encounters with Chinookan peoples 


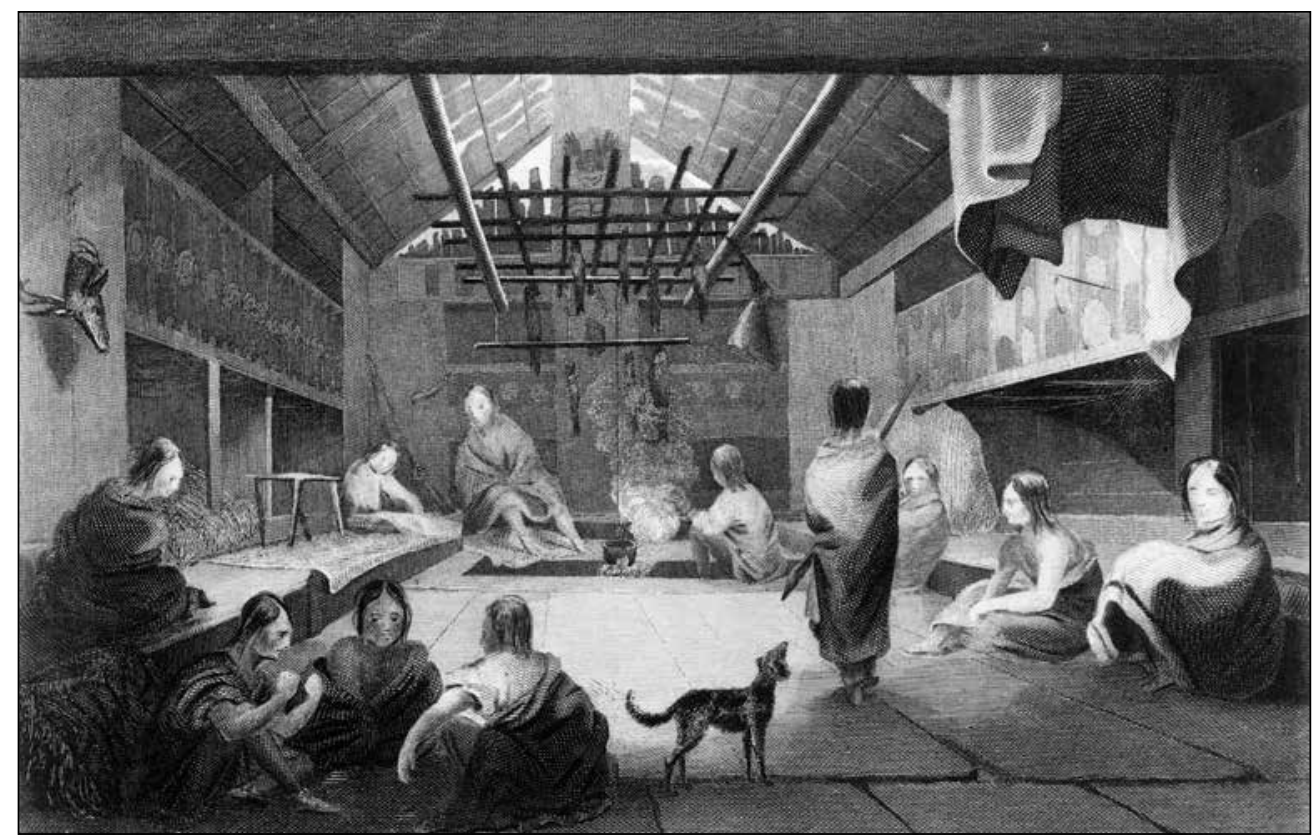

THIS ENGRAVING of the interior of a Clatsop lodge by R.W. Dodson was based on a field sketch made by Alfred Agate in 1841, which is produced on the following page for the first time in print. The engraving was published in volume 4 of Charles Wilkes's Narrative of the United States Exploring Expedition (1845).

in their homes often show fascination with the novelty and uniqueness of what they saw, and can be quite detailed. Here are two examples. The first, which describes the house of Chenamus, successor to Concomly and Chief at Chinook (perhaps figure 1, village 13, or possibly a nearby associated village), in August 1839, comes from the manuscript journal of Richard Brinsley Hinds, a member of the British Belcher expedition, and has never been published.The second, which describes the house of Chief Wanaxha at Willamette Falls (figure 1, village 44), is quoted from the 1835 journal of the Reverend Samuel Parker, who surveyed the Columbia for the American Board of Commissioners for Foreign Missions to determine its suitability as a mission site.

We landed opposite two houses of the Che-e-lis [Chehalis, there for the fishing], where we spent half an hour... From the Cheelis we walked along the shore to Chiunamus House, look in at a Cheenooks house on the road. . . . At this house were two nets hanging up, one of large meshes, and stronger than the other, this was a sturgeon net, the other for catching salmon. 
The exterior of the chiefs house appears like a large pile of split fir wood, but the inside is arranged with much method, and some portion of comfort. We ascended by some rather rude steps, and then descended a like number within, although there was a door beneath, which might have saved us the ascent and descent. The door itself is rather an oddity, it was . . hung over the entrance like a guard over the eye glass of a telescope, and on going in or out was pushed on one side... . The chief had preceeded us, and on our entrance we found him seated 'a la Turque' [cross-legged] on a mat placed on an elevated platform at the extremity of the building. ... The interior was spacious, solid, and to all appearances, judiciously arranged. Numerous strange faces were looking at us from all directions but maintained a respectful distance and subdued curiosity. Many families congregate here, over which Chiunamus reigns as chief. . . Most of us thought it bore a close resemblance to the interior of a steam-boat, where the passengers are each accommodated with a small sleeping shelf. Down each side were two rows of berths of five each one being placed over the other, each devoted to one family. In this case twenty families would be accommodated in the building besides the

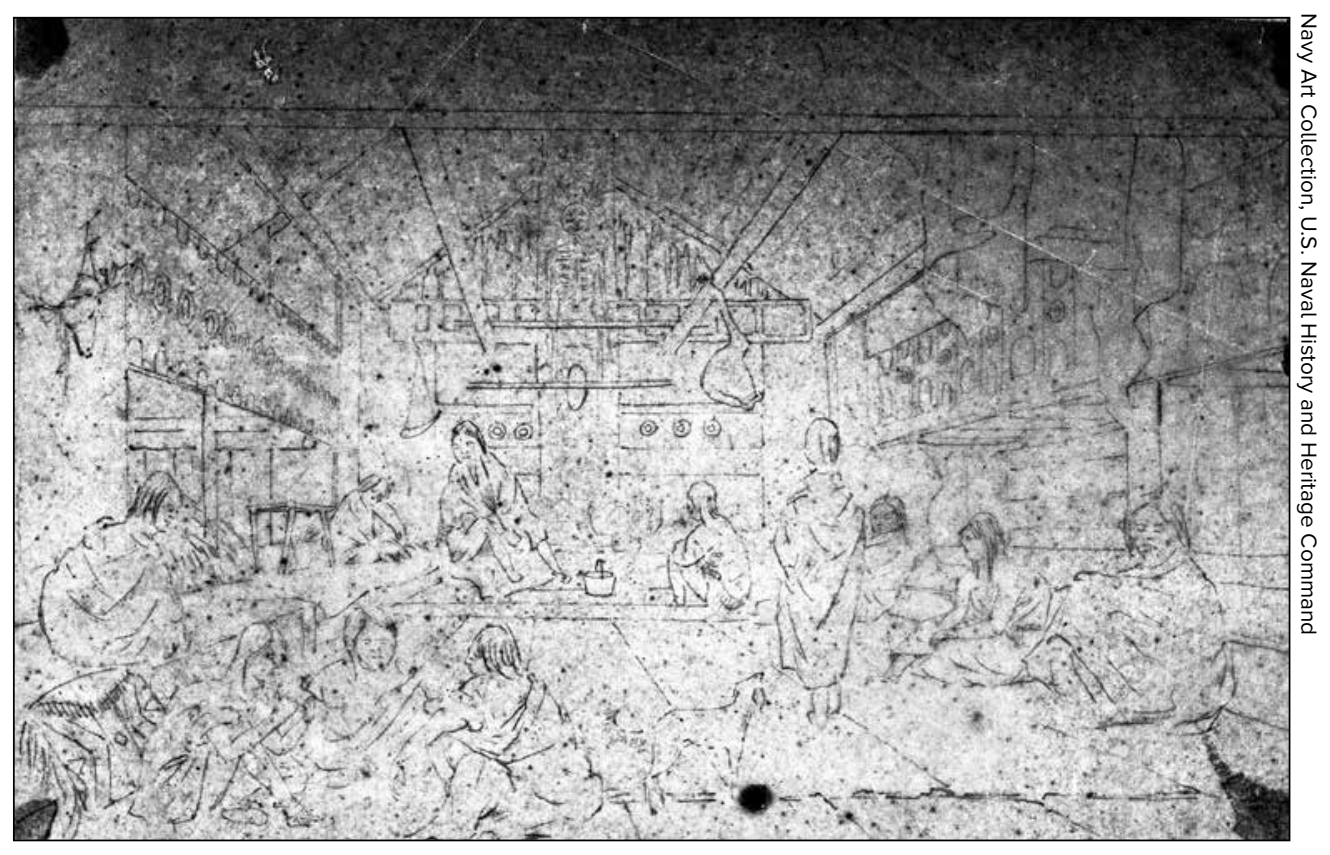

ALFRED AGATE'S 1841 FIELD SKETCH of a Clatsop lodge interior is credited as the basis of R.W. Dodson's engraving on the previous page. Wilkes's Narrative of the United States Exploring Expedition describes the village as consisting of "a few rough lodges, constructed of boards or rather hewn planks, of large size." Wilkes's Narrative also mentions "various uncouth figures of men" painted on the bunk planks and an elk's head hanging from one of the interior bunks, which is depicted on the left both in Dodson's engraving and Agate's sketch. 


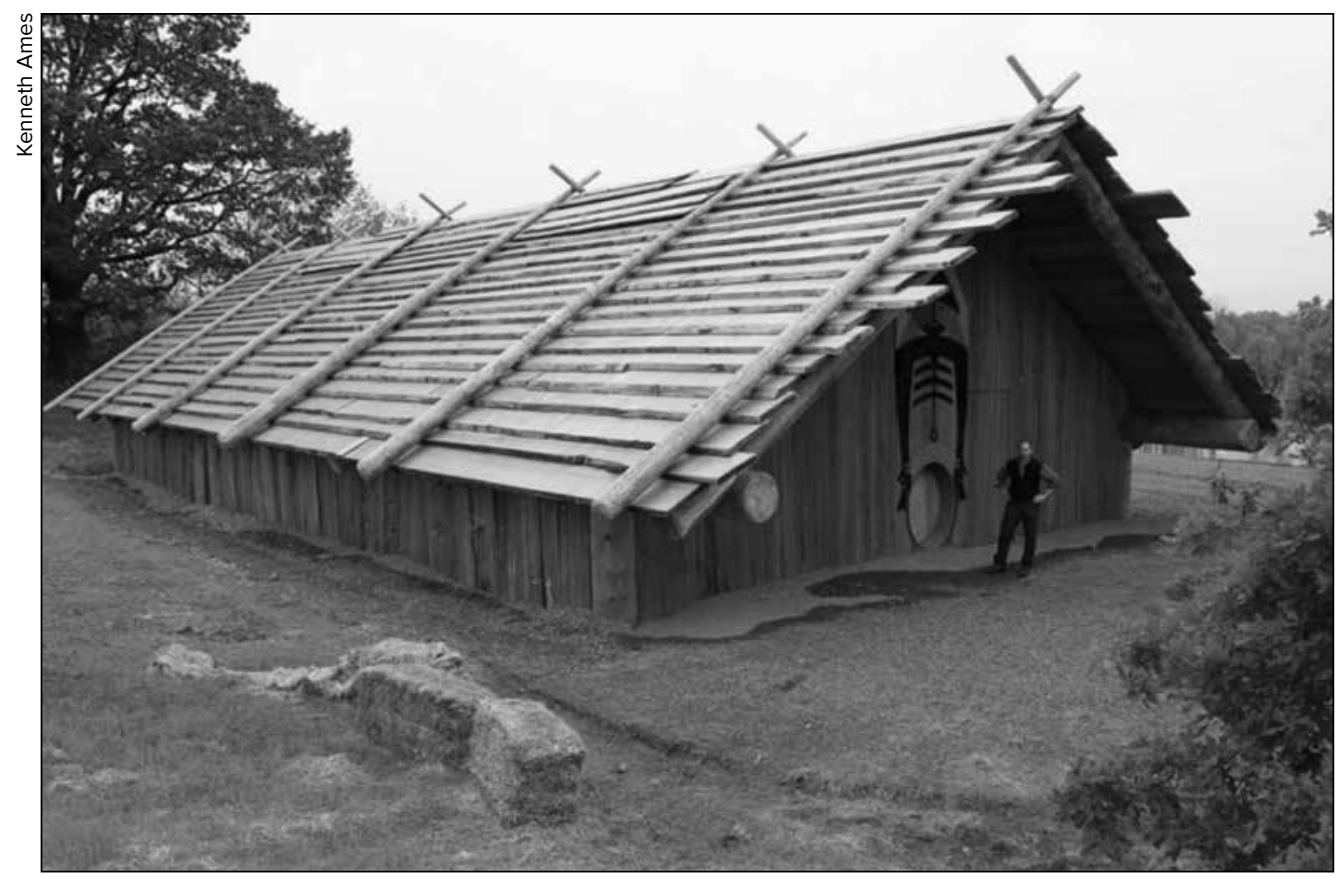

THIS CATHLAPOTLE PLANK HOUSE is a replica Chinookan long-house constructed in 2005-2006 near the archeological site of gáqap'uオx (figure 1, village 27), on the U.S. Fish and Wildlife Service's Ridgefield Refuge, near Ridgefield, Washington. It was built by members of the Chinook Nation, volunteers from the Ridgefield community, and the U.S. Fish and Wildlife Service. Cameron Smith of Portland State University stands at the front door.

chief who has separate quarters for his family. Opposite to each pair of berths is a fire, making altogether ten.... An escape for all the smoke is found in the top of the roof, the slanting sides of which are not quite in contact, but still are so placed as to keep out the rain. Behind the seat of the chief was a back board painted red with a slight relief of colored rings; and again behind this, forming the extremity of the house was a gigantic figure of red and black with long arms and five projecting ribs. A triangular red face, and horizontal figure-of-eight eyes. ... Two others of smaller size were stationed opposite to each other at the sides."

Notable in Hinds's description are: the rough plank exterior, door with steps, and overlapping cedar planks at the roof peak, which could be moved to let smoke escape or keep rain out; the multifamily nature of the dwelling twenty units (of unstated size) with sleeping shelves and two-family shared fireplaces; and the special place for the high-ranking family at the rear of the lodge, where Chenamus had his elevated seat and the ceremonial spirit board and large spirit figure were located. 
In November 1835, at Willamette village (figure 1, village 44), Chief Wanaxha invited Parker to spent the night in his house rather than camp outside. The house, according to Parker, was "a long building on the west side of the river, upon an elevation of one hundred feet, and near which were several other buildings of nearly the same dimensions. Besides the family of the chief, there were two other families in the same building in sections about twenty feet [apart], separated from each other by mats hung up for partitions." Each section had its own fireplace. In the chief's apartment, the eight-square-foot fireplace was sunk a foot into the earth and surrounded by a frame. Mats for the family to sit on were spread around it. Sleeping places were four feet above the floor, reached by ladders. Dried fish, roots, berries, and so on were stored underneath. ${ }^{12}$

The plank houses were central to the villages that in turn were the centers of Chinookan life and culture. ${ }^{3}$ Villages might be small, consisting of a single multifamily house - as at ničáq ${ }^{w} / i$ (Nichakwoli, figure 1, village

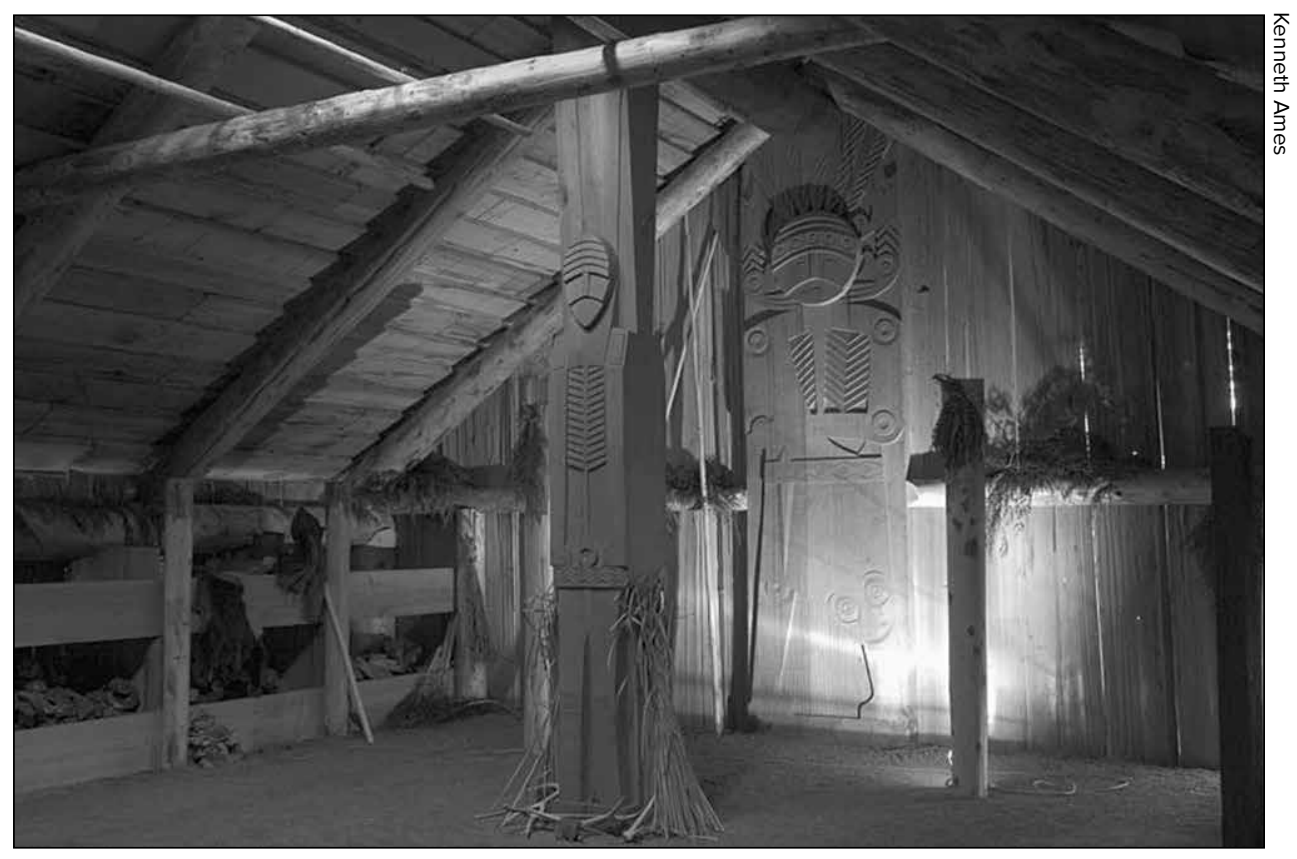

THE INTERIOR HOUSE POSTS of the Cathlapotle plank house replica were designed by Tony A. Johnson and carved primarily by Adam Mclsaac. In this and other public art projects, Johnson and Mclsaac adapt forms that aboriginally represented Chinookan spirit powers to the modern goals of public education. Here, instead of spiritually loaded images, it is the social structure of the traditional Native dwelling that is conveyed through the massive figure of a hereditary leader at the high-ranking end of the house. His father and mother, from whom he gained his status, are on the next post, and a connection to more distant ancestors are on a center post. 
48) with seven connected units and a population of one hundred - or as large as the thirty-six houses (a "deserted village") that Lewis and Clark saw in late fall of 1805 on the lower river. Villages seem to have paralleled the river, as Alexander Henry saw in 1814 at Oak Point (on the south side of Columbia River, not the north side where Oak Point sits on modern maps), where stood a "range" of eight houses some 140 feet in length and eight additional detached houses, or as Lewis and Clark saw at gáqap'u內x (Cathlapotle, figure 1, village 27), with its fourteen houses paralleling the Channel. ${ }^{14}$ They sometimes were arranged in clusters, as seems to have been the case with the villages centering on c'inúk (Chinook, village 13) or the three máqnumax (Multnomah) villages (figure 1, villages 32, 33, 34) on the Columbia bank of Sauvie Island. There were also sister villages occupied by the same people at different times of the year, as for instance gaławáiaxix (gatlawayakhikh), with a winter village near Stevenson and a summer village at Cascade Locks; or villages that had split off from each other, as šiámištix (Shiyamishtikh, figure 1, village 23) did from giłáxaniak (Kaniyak, figure 1, village 22).

Villages were linked through marriage. Because each Chinookan village was basically a group of relatives, marriage partners - usually the women - preferably came from outside. This created widespread networks of kin, especially for wealthier men who could afford more wives. Such ties facilitated travel and access to resource areas such as wapato wetlands and fishing sites. Lewis and Clark mention, for instance, that people from upriver came to relatives at Neerchokioo (figure 1, number 47) in November to gather wapato and hunt deer and elk. ${ }^{15}$

The size and population of villages varied seasonally, as people left or arrived in search of resources. During the winter, people in the Chinook, Willapa Bay, and Clatsop clusters (figure 1, villages 1-14) moved inland, coming back to the river in warmer weather for the fishing. After Fort Astor was built in 1811, villages on that part on the river came to be inhabited yearround, presumably to have greater access to trade opportunities at the fort. Elsewhere, movement was more varied. The Wapato Valley, especially, was crowded during warmer weather, when gáfap'u^x (Cathlapotle, figure 1, number 27), for example, tripled in size. Sometimes only the skeleton of a house was left standing, as the inhabitants took the boards or bark covering to construct temporary housing at a seasonal location.

All the ways villages were connected is not fully known today. In addition, the extent of traditional use areas - where people had rights to fish, or to gather wild plants - is not fully understood, although logically, they would be limited by foot and canoe travel. The seasonality of wild resources dictated some interesting movements - as from the Chinook villages 
on the north bank of the mouth of Columbia River to Willapa Bay, some Cascades peoples' seasonal migrations to Hayden Island or Willamette Falls, and Willamette Falls villagers' movement to the modern St. Johns neighborhood of North Portland. Salmon, eulachon, and wapato, in particular, drew people to the limited locations where they could be most easily harvested or were more abundant.

While Lewis and Clark estimated the number of houses that composed each village they documented, there were other structures they did not note. At gáqap'u^x (Cathlapotle) village, for example, there were fourteen houses, most of which were joined, according to Lewis and Clark. The archaeology, however, reveals six plank houses, four of them divided into a varying number of units, plus several outbuildings and temporary structures. ${ }^{16}$ Some of these may have been used to house slaves or visitors, for example. The accompanying painting of a Chinookan village in the Columbia Gorge by John Mix Stanley (see p. 10) may be a composite, but it certainly depicts the wide range of structures that could have been present in a single Chinookan village. These included fish-drying sheds or scaffolds, sweat and menstrual lodges, and temporary dwelling houses. Most fishing structures and cemeteries were located at a distance from villages.

Big houses, such as Chief Chenamus's at Chinook described by Hinds, were not typical. Such households may have become even larger in later

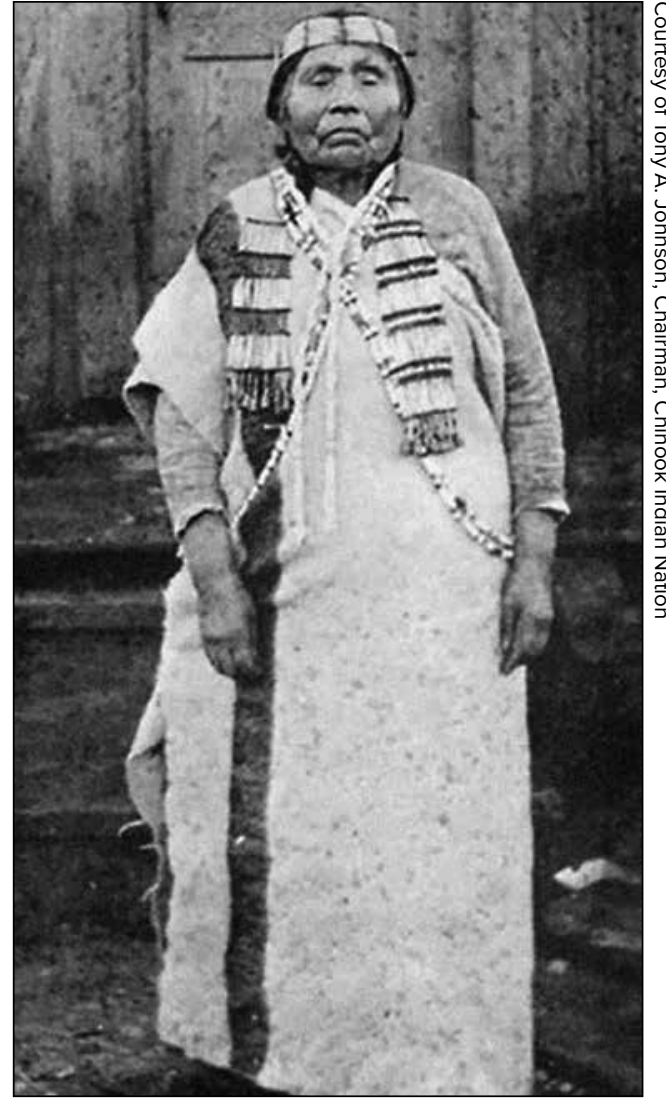

CHINOOK ELDER č'išt (CHISHT) (Catherine Hawks, later Catherine George) is pictured here in one of Edward S. Curtis's photographs. According to the Curtis team, she was born in about 1830 at wapłúcin (Waptlutsin), one of the villages belonging to the Chinook cluster (figure 1, villages 12-14, plus others listed only in the online version). She was the source of the Lower Chinook (Curtis: "Chinook") vocabulary appearing in volume 8 of Curtis's North American Indian manuscript. Her descendants compose a significant portion of the contemporary Chinook Nation. Her name means 'spruce-root burden-basket.' 


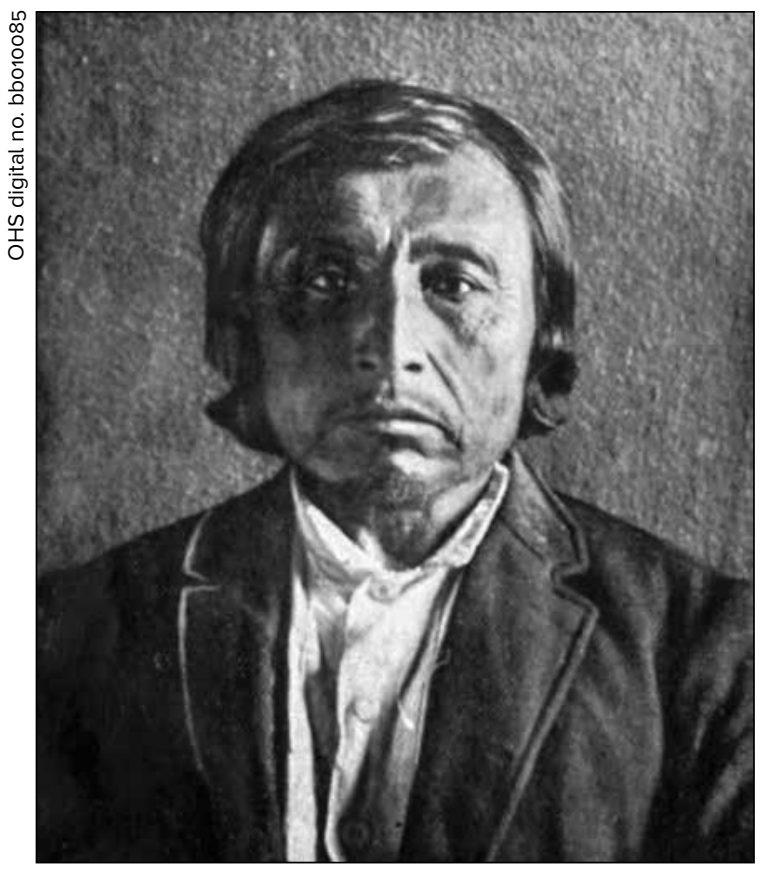

CHARLES CULTEE ( $\boldsymbol{q}$ 'əl/tí) is pictured here in about 1894 in an illustration from Franz Boas's Chinook Texts. Beginning in 1890, Cultee dictated two major collections of Chinookan-language texts to Boas, one composing the principal extant record of Lower Chinook, the other the principal extant record of Kathlamet Chinook. These collections also provide the most complete record of the traditional narrative art of the lower river. Cultee's genealogy well exemplifies the networks of kinship that transcended tribal and linguistic divisions on the lower river. years, as some men became wealthier through trade with Euroamericans. ${ }^{17}$ The contrast between Chenamus's house and Lewis and Clark's description of a Chinook house is illuminating. Lewis and Clark wrote that a house typically might hold one or two families, but sometimes three or four live in "one room":

they appear to be the father \& mother and their sons with their son's wives and children; their provision seems to be in common and the greatest harmony appears to exist among them. The old man is not always respected as the head of the family, that duty most commonly devolves on one of the young men. They have seldom more than one wife, yet the plurality of wives is not denyed them by their customs. ${ }^{18}$

Lewis and Clark do not mention slaves, but they were certainly present at least in wealthier households. Slaves were obtained by trade and capture from foreign tribes; they did most of the hard work of households, although poorer people probably did much the same. Speaking in about 1910, Chinook elder Chisht (Catherine Hawks) recalled:

Kamkámilli [Concomly] was chief at Utsǔmúiěkhan [ucmuyáqxan, one of the villages belonging to the Chinook cluster, figure 1, village 13] at the foot of the hill where Fort Columbia is now. He had several wives from different villages and had nine sons. His wives did no work, because he had two houses filled with slaves, and some besides in his own house. His slaves were obtained from the north and the south in trade. ${ }^{19}$ 
Hudson's Bay Company governor George Simpson caustically remarked, "every Flat Head Indian [lower Columbia free-born individual, customarily bearing the effects of frontal-occipital flattening during infancy] who is possessed of a slave considers himself a Chief." ${ }^{\circ}$

Each village might have one or more "chiefs," as all the early sources called them - basically, heads of households. The wealthiest and most influential was usually the village chief. Chiefs probably directed foraging activities and allocated resources for their households, and they might host religious ceremonies as well. They sometimes gave advice and helped settle disputes, but otherwise, families could do much as they pleased. With extensive kin networks, a chief's influence - but not power - might extend far outside the villages. ${ }^{21}$

\section{LISTING THE VILLAGES}

People have been listing and counting lower Columbia villages since at least the time of Lewis and Clark. The American explorers' two versions of the "Estimate of Western Indians" are the starting-point and touchstone for all other village lists, as they are the most detailed compilations from the period before the catastrophic fever and ague (malaria) epidemics of the early 1830s. ${ }^{22}$ Their lists include the village names in Chinookan (as well as the two English speakers could hear them and approximate a spelling using English letters), a general location, and number of houses and inhabitants. There is great variation in both spelling and population between the estimates

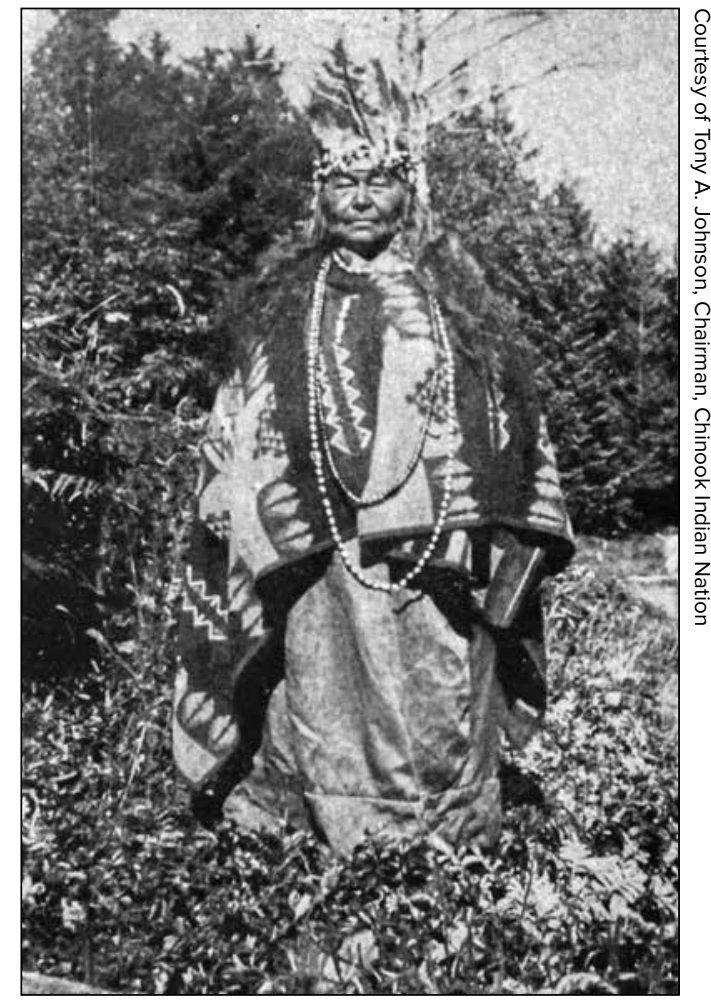

EMMA LUSCIER is the daughter of Sam and Esther Millett, who both supplied information to Edward S. Curtis's team. Verne Ray based his "Lower Chinook Ethnographic Notes" on information from Emma Luscier and another Willapa Bay elder, Isabel Bertrand, taken in conjunction with historical sources. She also provided extensive information on Willapa Bay traditions to the Smithsonian linguist John P. Harrington. 


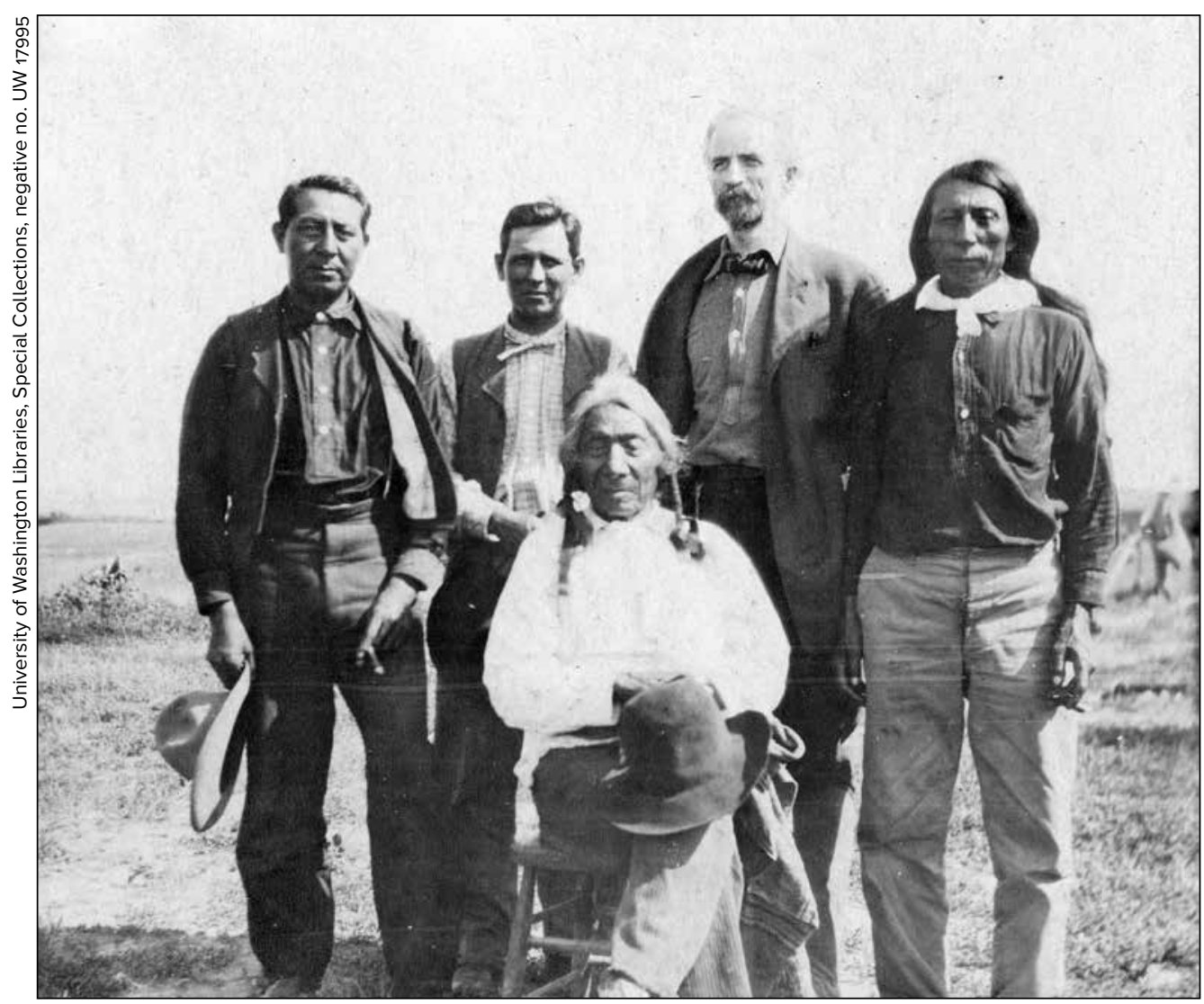

WILLIAM E. MYERS is believed to be standing second from the left, appearing in 1907 with A.B. Upshaw (far left), Edmond S. Meany (center), and Sioux leader Red Cloud (sitting) at the Pine Ridge Sioux Reservation. Myers joined Curtis's team in 1906 and soon became its chief ethnographer and linguist. Myers collected and wrote up much of the information for Curtis's volumes of The North American Indian, including that on tribal organization, history, and vocabulary. While Curtis's name is widely known today, Myers's has been virtually forgotten.

given by each explorer's list, and between those lists and references in their journal text and accompanying maps. ${ }^{23}$ From the subsequent Astorian and Northwest Company era, there are no lists per se, but many references in journals. Especially valuable is the Annals of Astoria, unpublished until 1999 and not used by any earlier compilers. From the Hudson's Bay Company era, Alexander Kennedy's 1824-1825 Fort George report has a partial list and census; and from the post fever and ague era, there is Meredith Gairdner's partial list, attributed to one of the original Astorians, Michel Laframboise. ${ }^{24}$ 
Leaving that era of direct documentation, we enter a period during which aboriginal villages had for the most part disappeared from the landscape, but not yet from the personal recollections and family traditions of local Native people. The best known sources in this category are Franz Boas's Lower Chinook and Kathlamet Chinook texts, dictated by Charles Cultee beginning in 1890; the lists of lower Columbia villages published in volumes 8 and 9 of Edward S. Curtis's The North American Indian; and Verne Ray's "Lower Chinook Ethnographic Notes," based on interviews conducted from 1930 to 1936 with two lower-river Chinook descendants, Emma Luscier and Isabel Bertrand. ${ }^{25}$ In common with previous compilations, the CPLC village list draws on all of these published sources. It also incorporates some related materials available only in archived manuscripts. Especially important among those newly accessed sources are a list of village names submitted by Boas to Livingston Farrand, one of the compilers of the Handbook of American Indians North of Mexico (first published 1907 and 1910); draft versions of Curtis volumes 8 and 9 (further discussed below); and the fieldnotes of the Smithsonian linguist and ethnographer John P. Harrington, who interviewed Emma Luscier and other local Native elders at length in $1942 .{ }^{26}$ During the late twentieth century, first archaeologists and sociocultural anthropologists, and then linguists revisited the early sources and produced Chinookan village lists of their own. ${ }^{27}$

While Boas, Curtis (or more properly, his linguist and ethnographer, W. E. Myers), and Harrington were all too late on the scene to add to the direct documentation of villages, it is to them that we owe our most accurate records of how Chinookans constructed and pronounced their village names. Northwest indigenous languages, including Chinookan, are characterized by many sounds that do not occur in English, and the English alphabet lacks the means to do justice to them. Historical spellings employing ordinary English alphabet symbols are not only inaccurate, but tend to be wildly inconsistent as well. Nor is it easy to find a middle ground between technical and nontechnical spelling, because details of pronunciation difficult or impossible to represent by ordinary English-alphabet means may turn out to be crucial for understanding the structure and meaning of a Native term. Figure 3 is a key to more commonly used linguistic transcription systems appearing in the lists of synonyms accompanying the village entries in the CPLC online list. Figure 2 is a guide to how speakers of Chinookan constructed typical names of peoples and places. For those interested in achieving the best possible non-expert approximation of a real Native pronunciation, we recommend studying the Curtis (that is, W.E. Myers) system. While this alphabet does not capture all of the distinctive sounds of the local languages to which it is applied, it is fairly 


\section{PLACES}

Prefix Position 1

$n$ - place of

$$
\begin{aligned}
& \text { Prefix Position } \mathbf{2} \\
& \text { number and gender of stem } \\
& \text { a- feminine sing (or: wa-) } \\
& \text { i- masculine sing (or: } w i-)
\end{aligned}
$$

\section{STEM}

Suffix

a noun -ix state, situation, or place of

Most place-names show at least a number/gender prefix in addition to the stem, for example:

$n-a ́-p ’ u \lambda x$ (see figure 1, village 27) 'Lewis River region' (prefix positions 1, 2; - p’u內x

\begin{tabular}{|c|c|c|c|c|}
\hline $\begin{array}{l}\text { Prefix Position } 1 \\
\text { people } \\
\text { or place of }\end{array}$ & $\begin{array}{l}\text { Prefix Position } \mathbf{2} \\
\text { number and gender } \\
\text { of stem }\end{array}$ & $\begin{array}{l}\text { Prefix Position } 3 \quad+ \\
\text { number and } \\
\text { gender of implied } \\
\text { possessor(s) }\end{array}$ & $\begin{array}{l}\text { STEM } \\
\text { a noun }\end{array}$ & $\begin{array}{l}\text { Suffix } \\
\text { plural, } \\
\text { place }\end{array}$ \\
\hline \multirow{4}{*}{$\begin{array}{l}g \text { - }(k \text { - before } q) \\
\text { 'those of' } \\
n \text { - place of }\end{array}$} & $i$ - masc. sing (or: wi-) & \multirow{2}{*}{\multicolumn{2}{|c|}{ ia- masculine singular }} & $-(u) k s ̌$ \\
\hline & a- fem. sing (or: wa-) & & & plural \\
\hline & $t$ - plural (or: it-) & & & - $\max$ \\
\hline & $\begin{array}{l}\$ \text { - neuter } \\
\text { collective (or: } i q-\text { ) }\end{array}$ & \multicolumn{2}{|l|}{$\begin{array}{l}\text { \$a- neuter } \\
\text { collective }\end{array}$} & $\begin{array}{l}\text { plural } \\
\text {-ix place, } \\
\text { state }\end{array}$ \\
\hline
\end{tabular}
probably for a local natural feature)

wa-tála (see figure 1, village 54) 'small lake' (prefix position 2; wa-tála is the name of Cascades Chinookans)

Most people-names show at least a number/gender and a possessive prefix in addition to the stem, for example:
$g$-á-4a-p'u內x (see figure 1, village 27) 'those of Lewis River region (Cathlapotle)' (prefix positions 1, 2, 3)
$g-a-\not a-w a ́-i a-x-i x$ (see figure 1, village 55) ' (those) of the face-place (Cascade Locks)' (prefix positions 1, 2, 3, 2, 3, suffix)
$g(a)-4$-ía-7išáqx-ix (see figure 1, village 21) 'those of the place of kinnikinnick berries (-Rišałx)' (prefix positions 1, 2, 3, suffix)

EXCEPTIONS: Some place/people names are based on unprefixed stems, such as šáxlat-kš '(those) upriver' (stem + suffix). The name of village 23 (figure 1) shows a variant form in which the order of the number-gender and possessive prefixes appears reversed: 4 -štá-mišt-ix.

ADDITIONAL EXAMPLES FROM FIGURE 1: The stem-forms underlying Chinookan village names are in many cases obscure (for example: $-p^{\prime} u \lambda x$ above). Most of those having known translations refer to floral, faunal, or topographic features; some point to a village's relative location. (Continued at the bottom on facing page.) 


\section{FIGURE 3: CHINOOKAN PHONEME SYMBOLS}

The phonemes (sounds serving to distinguish words) of Chinookan are: $p, t, \lambda, c, \check{c}, k, k^{w}, q, q^{w}, 7, b, d$, $g, g^{w}, \dot{g}, \dot{g}^{w}, p^{\prime}, t^{\prime}, \lambda^{\prime}, c^{\prime}, \check{c}^{\prime}, k^{\prime}, k^{\prime w}, q^{\prime}, q^{\prime w}, q, s, \breve{s}^{\prime} x, x^{w}, x, x^{w}, l, m, n, w, y, a, i, u,{ }^{\prime}$ (Handbook of North American Indians, vol. 7, 1990, 533).

\begin{tabular}{|c|c|c|c|c|c|c|c|c|c|c|c|c|c|c|c|c|c|c|}
\hline $\begin{array}{c}\text { Americanist } \\
\text { (Jacobs } \\
1958-89 \text { ) }\end{array}$ & $\lambda$ & C & $\check{c} \check{c}$ & $q$ & $?$ & $\mathrm{~g}$ & $p^{\prime}$ & $t^{\prime}$ & $\lambda^{\prime}$ & $c^{\prime}$ & č' & $k^{\prime}$ & $q^{\prime}$ & $q$ & $\check{s}$ & $x$ & $\underline{x}$ & $\partial^{*}$ \\
\hline $\begin{array}{l}\text { W.E. Myers } \\
\text { (Curtis 1911) }\end{array}$ & thal & $\widehat{\mathrm{ts}}$ & ch & $\begin{array}{l}\mathrm{k}, \\
\mathrm{k}\end{array}$ & ، & $\begin{array}{l}\text { k, } \\
\text { k }\end{array}$ & $\mathrm{p}$ & $\mathrm{t}$ & th। & $\widehat{\mathrm{ts}}$ & ch & $\begin{array}{l}\mathrm{k}, \\
\mathrm{k}\end{array}$ & $\begin{array}{l}\mathrm{k}, \\
\mathrm{k}\end{array}$ & ЂI & sh & $\dot{\mathrm{h}}$ & $\dot{\mathrm{h}}$ & ŭ \\
\hline $\begin{array}{l}\text { Americanist } \\
\text { (Boas 1894) }\end{array}$ & L & ts & tc & $q$ & $\varepsilon$ & $q$ & $\mathrm{p} !$ & $\mathrm{t} !$ & L! & ts! & $\mathrm{tc!}$ & $\mathrm{k} !$ & $\mathrm{q} !$ & L & C & $x$ & $x$ & $E$ \\
\hline $\begin{array}{c}\text { Americanist } \\
\text { (Jacobs 1929) }\end{array}$ & $t \dagger$ & ts & tc & $q$ & , & $\underline{g}$ & $p^{\prime}$ & $t^{\prime}$ & $t^{\prime} \phi$ & t's & t'c & $\mathrm{k}^{\prime}$ & $q^{\prime}$ & $t$ & C & $x$ & $\underline{x}$ & $\partial$ \\
\hline $\begin{array}{c}\text { Harrington } \\
(1942)\end{array}$ & t & ts & $t \int$ & $\mathrm{K}$ & , & G & $p^{\prime}$ & $\mathrm{t}^{\prime}$ & $\mathrm{t} \phi^{\prime}$ & ts' & $\mathrm{t}{ }^{\prime}$ & $k^{\prime}$ & $\mathrm{K}^{\prime}$ & 4 & $\int$ & $x$ & $x$ & $\begin{array}{l}\partial, \\
\alpha\end{array}$ \\
\hline
\end{tabular}

THIS CHART SHOWS selected Americanist phoneme symbols used by Melville Jacobs, Clackamas Chinook Text (1958-59) with corresponding symbols in Edward S. Curtis, The North American Indian, vol. 8, (1911); Franz Boas, Chinook Texts (1894); Jacobs, Clackamas Chinook field notebooks (1929); and John P. Harrington, field notes (1942). Jacobs's later system is basically identical to that of the Handbook, except that his " $g$ " is used instead of the Handboook's $\dot{g}$; and he adds the segment ə (see note below). For a simplified (incorrect) pronunciation of Chinookan names and words: pronounce vowels as in Italian or Spanish, consonants as in English, with adjustments following the Myers/Curtis system.

* ə (called "schwa"), while phonetically a vowel, is not a vowel phoneme in Chinookan. In his Clackamas Chinook transcriptions, Jacobs sometimes retains it, sometimes omits it. We retain it when it helps to clarify the syllable structures of the words in which it occurs. It varies in quality, depending on the values of adjacent consonants.

(These notes refer to additional examples from figure 1, continued from facing page.)

9. $t$-iá-k'ilak-ix 'those of the place having pounded salmon'

14. qíq'ayaq-ilxam 'middle-town'

20. $g(a)-4-i a ́-\check{s} g \partial n(\partial)-m a x-i x$ 'those of the place of cedars'

23. $q(a)-\check{s}-i a ́-m i \check{s} t-i x$ 'those of the place of the (river) mouth ( $\check{s}-i a ́-m i s ̌ t) '$

30. g-a-4á-q'map 'those of the mound'

34. máqnu-max 'those towards water (or towards the Columbia River)'

41. $g$-a-4á-k'anasisi 'those of the diver-ducks (wá-k'anasisl)'

This chart was compiled by the authors with reference to Walter Dyk, "A Grammar of Wishram" (Ph.D. diss., Yale University, 1933); Dell Hymes, "The Language of the Kathlamet Chinook," (Ph.D. diss., Indiana University, 1955); and Silverstein, "Chinookans of the Lower Columbia," 533, n. 534. 


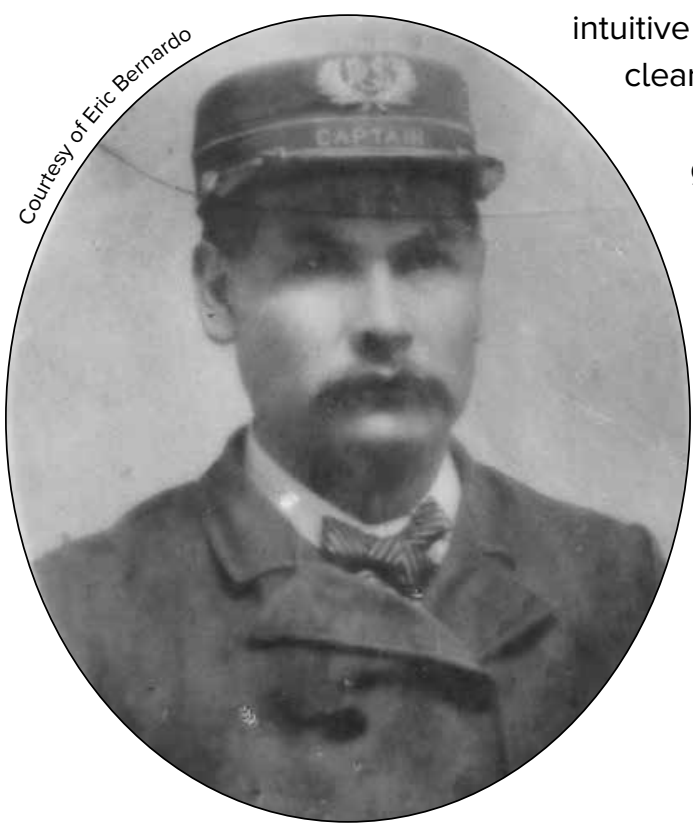

MARSHELL MARTINEAU served the Curtis team as river pilot, interpreter, and source of Chinookan village names. Named after his French Canadian father, Martineau's first name appears also as Michel and (incorrectly) as Michelle. His mother was Cascades Chinookan, a sister of Virginia Miller, whose Cascades Kiksht was interpreted by Martineau to the Curtis team.
Of the eighty-plus village and group names appearing in the CPLC online list, about half (forty-three) come with translations (see figure 2 for selected examples, and to the online list for more detailed information). Ignoring problematic translations, there remain thirty-eight examples that refer to geographic features (for example, 'those of the place of the river mouth'); thirteen that refer to characteristic local flora or fauna (for example, 'those of the place of kinnikinnick berries'); eight related to relative location (for example, 'middle-town'); and five related to human activities (for example, 'those of the place having pounded salmon'). The pattern suggested by this sample is broadly consistent with placenaming in adjacent indigenous cultures. The most ambitious recent study in this genre is the

Umatilla Tribe's 2015 Čáw Pawá Láakni / They Are Not Forgotten: Sahaptian Place Names Atlas of the Cayuse, Umatilla, and Walla Walla. ${ }^{28}$ The Atlas's 117 translated village names refer to geographic features, human activities, and local plants and animals.

\section{THE CURTIS COMPILATION}

The longest single list of lower Columbia village names compiled primarily from the memories of Native elders was published in Edward S. Curtis's monumental The North American Indian. The CPLC village list draws on recently uncovered draft versions of those volumes, which, as far as we know, have never before been utilized. This previously unused documentation supplements the published Curtis village list with important detail that did not survive the transition from Curtis's draft village lists to his final published versions. It also corrects a number of slips made in that transition. 
These additions and corrections are all the more important because the published versions were a principal source drawn on by the compilers of the two village lists appearing in volumes 7 and 12 of the Handbook. ${ }^{29}$

Curtis's The North American Indian volume 8 includes a section devoted specifically to Chinookan peoples of the lower Columbia; volume 9 has some relevant supplementary information in a section on neighboring Salishan peoples. ${ }^{30} \mathrm{Cur}$ tis's ethnographer and linguist, a man named William E. Myers, worked in Curtis's shadow, so much so that his name does not appear in the printed volumes in association with the linguistic and ethnographic content for which he was primarily responsible. Curtis's volume introductions credit Myers only for "able assistance." ${ }^{31}$ Also conspicuous by their absence are the identities of the individuals who were the ultimate sources of the

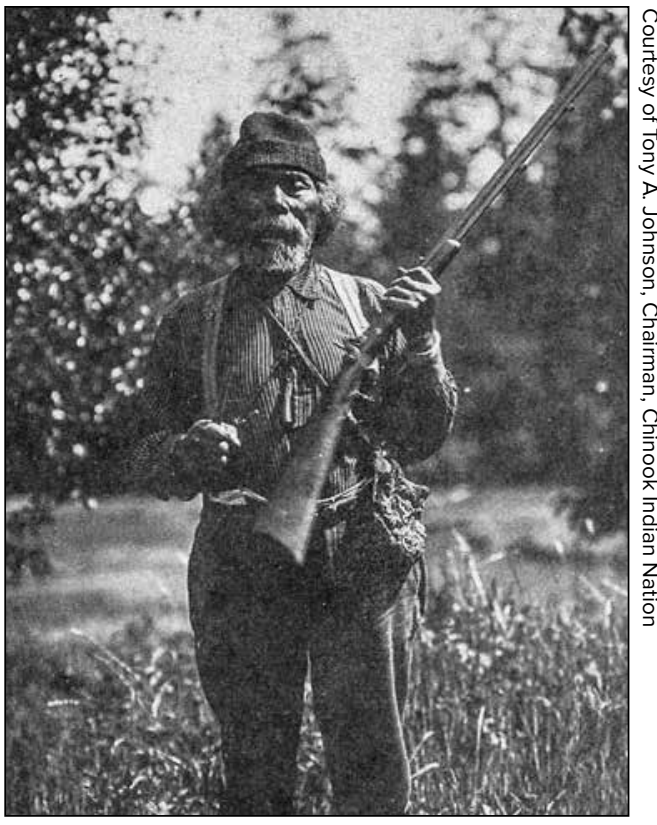

SAM MILLETT, a speaker of Kathlamet Chinook and Willapa Bay Salishan, was one of the Curtis team's principal lower river consultants. His name appears in volume 9 of Curtis's The North American Indian manuscript as "Ṭloloh" and his place and year of birth as Bay Center, Washington, in about 1832. village names written down by Myers. While Myers must have made an original field record, this has so far not been located, if it has in fact survived. What we do have, thanks to leads supplied by the recent research of Mick Gidley, are copies from draft versions of volumes 8 and $9 . .^{32}$

According to those drafts, most of the forty-eight lower river Chinookan village and other group names published in volume 8 and falling within the limits of our figure 1 were contributed by two men: Sam Millett, a Kathlametspeaking resident of Bay Center, Washington, said to be about eighty years old when interviewed; and Marshell (often encountered as Michelle) Martineau, a riverboat captain by occupation, and the son of a French Canadian father and a Cascades Chinook mother. Also contributing information to the project were Martineau's Cascades aunt, Kamágwaih (Mrs. Virginia Miller), as interpreted by her nephew; Catherine Hawks (also known as Catherine George, or by a Chinookan name, Chisht), source of the Lower Chinook (Chinook proper, or "Chinook" in Curtis) vocabulary list published in volume 8; 


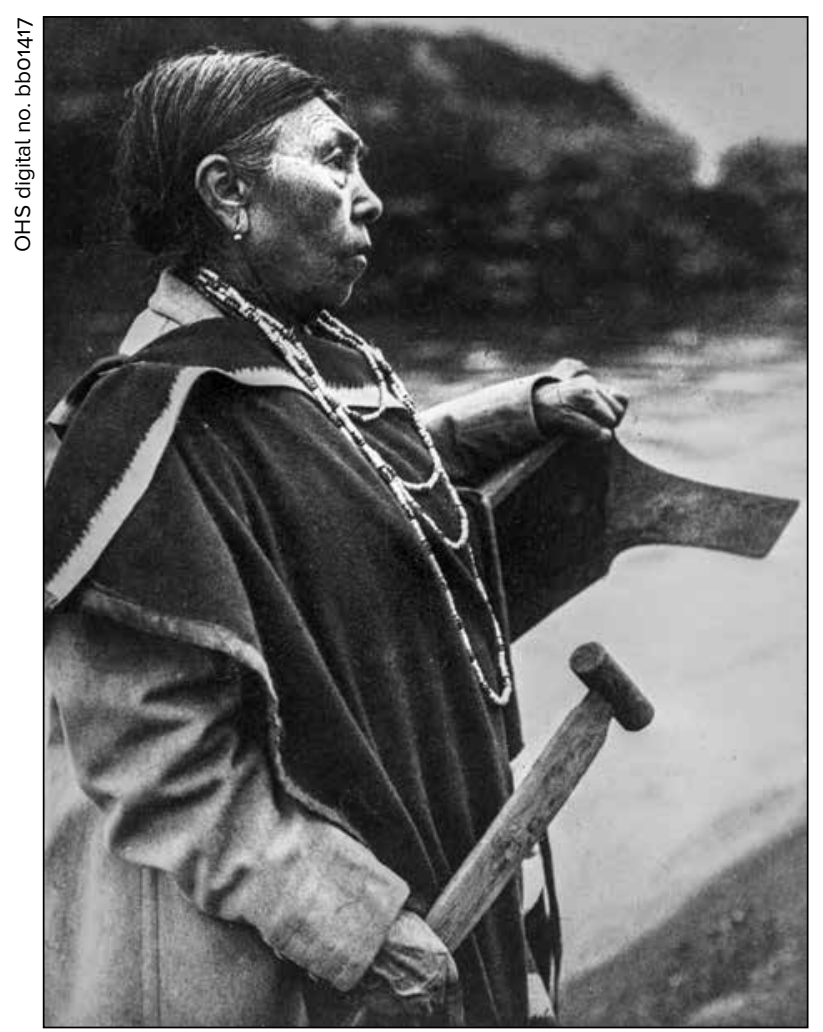

VIRGINIA MILLER, Cascades Chinook, is pictured here in a 1910 Edward Curtis photograph. The Curtis team recorded her Cascades name as "Kamágwaih." Chuck Williams, a contemporary descendant, gives her name as "Why-lick Quiuck." The Curtis team interviewed her at length. Their interpreter was her nephew, Captain Marshell Martineau. and Esther Millett, Sam Millett's wife, a Cowlitz Salishan speaker who supplied information published in volume 9 , including the names of several lower Cowlitz River villages reportedly occupied jointly by Salishan speakers and Kathlamet speakers.

The list published in volume 8 , in particular, omits various information preserved in the draft version. Some of those omissions are of considerable historical interest, notably, Sam Millett's identification of four villages occupied by the Clatskanies, an Athapaskanspeaking lower Columbia people about whom very little else is known (see figure 4). The survivors of these villages were probably among the twenty-seven Clatskanies rounded up in late 1855 and placed on a temporary reserve at Milton near St. Helens, preparatory to (an unconfirmed) removal to the new Grand Ronde Reservation. ${ }^{33}$ The information on Clatskanies from Millett is new to scholars. Looking at the list as a whole, Martineau was the source of Cascades and lower Willamette region village names, and Millett of coastal and lower-river village names. Their two lists intersect in the Wapato Valley and Downstreamers geographical-historical clusters. The Curtis editors' attempt to integrate the two lists into a single seamless whole for publication was not entirely successful, as can be gathered from the comparisons provided in figure 5 . In the Wapato Valley, the Curtis editors combined Martineau's identification of name 37 - associating it with Sauvie Island as a whole - with Millett's 


\section{FIGURE 4: VILLAGE INFORMATION GIVEN BY SAM MILLETT}

BUT LEFT UNPUBLISHED BY CURTIS

\begin{tabular}{|c|l|}
\hline Nú'smá'spu & $\begin{array}{l}\text { In published list (see online list, note to nos. 5-11 [Clatsop villages]): but omitting the informa- } \\
\text { tion that it "was probably named by the Hlatskanai [Clatskanie], as that language was used } \\
\text { there." }\end{array}$ \\
\hline Ḳi-দhlá-u-na-thlh & Clatskanie village at head of Youngs River estuary \\
\hline Ḳa-wi-lŭm-kók & Clatskanie village of 4 houses at Westport, Oregon \\
\hline Wéĕ-ktlok & Clatskanie and Kathlamet (Chinookan) village of 5 houses at Clatskanie, Oregon \\
\hline
\end{tabular}

\section{FIGURE 5: OVERLAPPING VILLAGE LISTS FROM SAM MILLETT AND MARSHELL MARTINEAU} AS PRESERVED IN THE DRAFT VERSION OF CURTIS'S VOLUME 8

\begin{tabular}{|c|c|c|}
\hline $\begin{array}{l}\text { Figure } 1 \\
\text { Village Name }\end{array}$ & Sam Millett & Marshell Martineau \\
\hline 15. gaqámat & $\begin{array}{l}\text { Ka-hlá-a-mat: village of } 7 \text { houses at } \\
\text { Cathlamet Head (Aldrich Point, Oregon) }\end{array}$ & 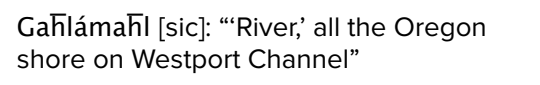 \\
\hline 21. gadia?išáqxix & $\begin{array}{l}\text { Ka-দ̆li-ă'-i-sháhl-hih: abandoned } \\
\text { village at modern Cathlamet, Washington }\end{array}$ & $\begin{array}{l}\text { Isáhந̄| "the first village of Itkigwálatkşh } \\
\text { ('downstreamers')" }\end{array}$ \\
\hline 25. gałák'alama & no entry & $\begin{array}{l}\text { Kálamat "mouth of Kalama river," Cowlitz } \\
\text { [Salish] speaking }\end{array}$ \\
\hline 27. gáłap’u內x & no entry & $\begin{array}{l}\text { Winlkt "the country about the mouth of } \\
\text { Lewis River, inhabited by Klickitat[s]" }\end{array}$ \\
\hline 37. gađánaqwaix & $\begin{array}{l}\text { Na-qaí-ih [ } 4 \text { miles from no. 31, on } \\
\text { Willamette Slough] }\end{array}$ & $\begin{array}{l}\text { Nakwwaííh "the country between Willamette } \\
\text { river and Willamette slough" } \\
\text { Gahlanákwaiih [the people of ... . }\end{array}$ \\
\hline 31. sqápus & Skáp-pus [as in Fig 1] & no entry \\
\hline 28. náiaguguix & Naí-ya-ku-kuih [as in Fig 1] & no entry \\
\hline
\end{tabular}


placing of villages 37, 31, and 28 along Multnomah Channel. The result is an artificially constructed "tribe" name showing Martineau's form for name 37 (with gaqa- 'the people of . . . ') embracing Millett's three villages, one of which shows the same "tribe" name, but with the place-name prefix na- "place of ... ' rather than gaqa- 'the people of ... '. As far as we know, this imposed classification receives no independent support.

The draft version also shows that although Martineau's knowledge becomes progressively sketchier the farther downriver it ranges, he nevertheless offers information that, taken in conjunction with other evidence, has important implications for reconstructing the later history of the Downstreamers/Kathlamet cluster. While his explanation of village name 15 (source of the modern English local name Cathlamet) is a patent "folk etymology" (turning on an inexact coincidental resemblance between the last syllable of the name and the Chinookan noun - ma ' 'river'), his usage of the Chinookan itgíg walatkš 'downstreamers' descriptor (Itkigwalatksh in Curtis) for village 21 provides important confirmatory evidence that itgígwalatkš was a Chinookan geographical and ethnic term coordinate with šáxlatkš 'upstreamers', the latter being well documented as a collective name of Cascades Chinookans. Similarly, his attribution of sites 25 and 27 to non-Chinookan peoples, taken together with other historical evidence, provides a window on the cataclysmic demographic shifts that overtook this region during the early nineteenth century, especially following the fever and ague epidemics of the early 1830s. His information that the mouth of Lewis River (figure 1, village 27) had been inhabited not by Chinookans, but by Klickitats (Sahaptin speakers), constitutes an especially poignant reminder of the fragility of historical memory in an oral culture. ${ }^{34}$ This location (named in Figure 1 following other sources, as neither Millett nor Martineau seem to have remembered it) had earlier been the site of a large and thriving Chinookan village center, as described by Lewis and Clark in 1805 and $1806 .{ }^{35}$

\section{FURTHER CONTRIBUTIONS OF THE CPLC LIST TO LOWER COLUMBIA ETHNOHISTORY}

The new list contains many additional observations contributing to a fuller picture of the historical lower Columbia. Here are some examples.

One feature of lower river geographic names that has previously been known, but which receives additional confirmation in the sources newly accessed by the Chinookan Peoples list, is the coexistence of Salishan and Chinookan names for many of the same places and groups, especially in the Willapa Bay, Chinook proper, and Downstreamers/Kathlamet village clusters. This feature has its background in patterns of intergroup 
marriage that crossed both political and linguistic boundaries, resulting in extensive Chinookan-Salishan bilingualism on the lower river. Indeed, the name "Chinook" itself (originally, a name of village 13) is believed to be of Lower Chehalis Salishan origin. ${ }^{36}$ The following three lower-river villages show cross-translating Chinookan names first, followed by Salishan names. As illustrated in figures 1 and 2, many Chinookan geographic and ethnic names are based on descriptive terms for local landscape or other natural features, lending themselves quite readily to variably inflected Chinookan forms (see figure 2 ) as well as cross-translations into neighboring languages:

Village 4. tiápšuyi (Tiyapshuyi) 'grassy place' : pácčł (Patschitl) 'grass'

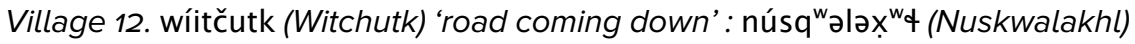
'where the trail comes out'

Village 14. qíq'ayaqilxam (Kikayakilkham) 'middle town' : k'acámc' (Kwatsamats) 'in the middle'

It is possible that the name "Skilloot(s)," one of the great mysteries of lower Columbia ethnohistory, belongs to another Chinookan-Salishan pair, although documentation is insufficient to support more than a hypothesis to that effect. The name is from Lewis and Clark, who used it with reference to Native people along a long stretch of the lower river, but most especially, to the people known in Kiksht Chinookan as itgig'alatkš 'downstreamers'. It is the lack of any subsequent unambiguous attestation of "Skilloot(s)" that renders it such a mystery. Scholars have proposed several explanations of the term over the years, and some additional candidates have since come to our attention (see figure 6). One of these candidates presents coincidences of form and meaning that Zenk finds compelling: squlút (Skulut), recorded by Harrington as a Salmon River Tillamook term meaning 'valley' and applied by those coast-dwelling Salishan speakers to interior valley-dwelling Kalapuyan peoples who lived to their east. In Zenk's judgment, this raises the possibility that a Salishan term like squlút was at some time in wider use, presumably with reference to foreign-speaking people living in a valley or interior location, and only had dropped out of use on the lower Columbia by the time the linguists arrived on the scene.

This identification, if true, would not be the only instance in our village list of a Lewis and Clark ethnic name that failed to find direct confirmation from the linguists but turns up either as a name in a neighboring (non-Chinookan) language or as a Chinookan local name. We have found two such instances in the Willamette Falls cluster: villages 45 and 46. Lewis and Clark never 
FIGURE 6: THE KATHLAMET/ITKIGWALATKSH REACH, TWO PROBLEMATIC NAMES

\begin{tabular}{|c|c|c|}
\hline Name & Proposed Sources & Comment \\
\hline \multirow[t]{5}{*}{ Skilloot(s) } & s(i)k’ə/útk “look at him!” & $\begin{array}{l}\text { Proposed to explain Lewis and Clark's earlier, less } \\
\text { geographically specific references to Skilloots.' }\end{array}$ \\
\hline & $\begin{array}{l}\text { sqúlups (name of Cape Horn, } \\
\text { Washington) }\end{array}$ & $\begin{array}{l}\text { Proposed to explain Lewis and Clark's references } \\
\text { to Skilloots in the in the Kathlamet/ltkigwalatksh } \\
\text { Reach.' }{ }^{2} \text { Note: there are two Cape Horns on the lower } \\
\text { Columbia River: one east of Cathlamet, Washington; } \\
\text { the other in the Columbia Gorge (east of Washougal, } \\
\text { Washington). Skulups is for the latter, not the former } \\
\text { Cape Horn. }\end{array}$ \\
\hline & sǵúlus & $\begin{array}{l}\text { Cited as a possible explanation of the name } \\
\text { Skilloot(s). }{ }^{3} \mathrm{Cf} . n(\partial) s k \text { 'əlús, a Clatsop Chinook } \\
\text { local name. }{ }^{4} \mathrm{Cf} \text {. isgúlus, a noun with dual is- (s- in } \\
\text { downriver dialects), recorded as Clackamas Chinook } \\
\text { for 'black vulture' (identification uncertain). }{ }^{5}\end{array}$ \\
\hline & Calooit, Kreluit & $\begin{array}{l}\text { Cited as synonyms of Skilloot(s). }{ }^{6} \text { Note: more } \\
\text { plausibly explained as renderings of (i) } 4 x / \text { xúit 'they } \\
\text { are strange, different', for people of interior Cowlitz } \\
\text { River.7 }\end{array}$ \\
\hline & squlút & $\begin{array}{l}\text { Salmon River Tillamook term said to mean 'valley, } \\
\text { prairie'. Also attested in squlútwəš 'valley Indian', } \\
\text { referring to Kalapuyans of the Willamette Valley.8 }\end{array}$ \\
\hline \multirow[t]{2}{*}{$\begin{array}{l}\text { Chilwitz (Hellwits, } \\
\text { Whill Wetz) }\end{array}$} & Cf. ? X w’ólcš 'go downstream' & $\begin{array}{l}\text { Local Salishan term, proposed by CPLC compilers } \\
\text { as the possible source of the name Chillwitz, which } \\
\text { is either a synonym for the name of village } 22 \text { or the } \\
\text { name of a group closely related to village } 22 \text {. }\end{array}$ \\
\hline & Cf.? sč’ə/əhát & $\begin{array}{l}\text { Nehalem Tillamook name of the Clatskanie } \\
\text { (Athapaskan) language, spoken on the south side of } \\
\text { Columbia River. }{ }^{9}\end{array}$ \\
\hline
\end{tabular}

1, 2. Silverstein, "Chinookans of the Lower Columbia," 545.

3. Leslie Spier, "Tribal Distribution in Washington," General Series in Anthropology 3 (1936), 23.

4. Harrington, Papers, mf 17.0855.

5. Melville Jacobs, Clackamas Chinook field-notes, 1929-30 (notebook no. 65, page 57), Melville Jacobs Papers, University of Washington Libraries, Seattle. The original reference may have been to the California condor, frequently seen on the lower Columbia before the mid nineteenth century.

6. Handbook of American Indians North of Mexico, ed. Frederick Hodge, 2 vols., Smithsonian Institution, Bureau of American Ethnology Bulletin 30 (Washington, D.C.: U.S. Government Printing Office, 1907-10), 545, 591.

7. Silverstein, "Chinookans of the Lower Columbia," 545.

8. Harrington, Papers, mf 20.0340; (source: Louis Fuller, a speaker of Salmon River Tillamook).

9. Harrington, Papers, mf 17.0836 (source: Clara Pearson, a speaker of Nehalem Tillamook; the information appearing in the Handbook of North American Indians, 7 (1990), 532, that this was recorded as Lower Chehalis is in error). 
visited the Willamette Falls but described it and named two villages there on the basis of information given by Natives along the Columbia River. Neither of these names receives unambiguous confirmation from later records of Chinookan. We believe, however, that the sources offer enough information to fill in the blanks:

Village 45. Lewis and Clark's "Charcowah." No unambiguous Chinookan match has been found, but in the neighboring Molala language, spoken in the Cascade foothills to the east of Willamette Falls, Oregon City (the principal contact-era town at the falls) was called čaká'wa (Chakawa) - by implication, Lewis and Clark's village name, preserved as a local name in a neighboring language after the village itself had been forgotten.

Village 46. Lewis and Clark's "Cushooks." The Handbook offers an ingenious explanation of this name: that it refers to contrasting pronunciations of commonly used conjunctions in two varieties of Kiksht, one spoken in an area including Willamette Falls, the other farther east. ${ }^{37}$ But a Willamette Falls village name of like form was independently recorded by Philip Drucker from one of the last speakers of Clackamas River Kiksht, John Wacheno. ${ }^{38}$ While Drucker's transcription cannot be considered accurate, it strongly suggests a lower-Willamette place-name recorded in myth by Jacobs: k'ášxəkš(ix) (Kashkhaksh). ${ }^{39}$ While this case remains complicated (yet another possibility suggests itself: ikišačk (Ikishachk), the Chinookan word for 'falls', documented with reference both to Willamette Falls and the Cascades of the Columbia River), the resemblances of form and geography cited suggest that a name preserved only in myth in Jacobs's Clackamas corpus can be identified with Lewis and Clark's village name.

These are but a few selected examples of cases in which the CPLC village list leaves us with new data to crunch, despite not providing definitive resolutions of all old problems. As the important new documentary discoveries contained in the CPLC village list prove, we should not take it for granted that this compilation, any more than any of those previous to it, will be the last word on the subject. The primary documentation on lower Columbia villages - archaeological, ethnohistorical, and linguistic - continues to grow as new data and source materials are discovered, more than two centuries after Chinookan peoples were first encountered by Euroamericans. And with this new material, researchers continue to learn more about the Chinookan villagers of the lower Columbia. Our task here has been to call attention to the recent research compiled in CPLC and its comprehensive online village list, including data accessed and analyzed in the past few years. 
1. Robert Boyd, Kenneth Ames, and Tony Johnson, eds., Chinookan Peoples of the Lower Columbia (Seattle: University of Washington Press, 2013; paper reprint 2015).

2. See table s2.1, Henry Zenk, Robert Boyd, and David Ellis, "Lower Columbia Chinookan Villages: Named Sites from Contemporary Observers or Multiple Primary Sources" (supplement to David V. Ellis, "Cultural Geography of the Lower Columbia," Chinookan Peoples), available at www.anthropology.pdx. edu/chinookanpeoples.php (accessed February 9,2016$)$. On the historical demography of Chinookan peoples, see Robert Boyd, "Lower Chinookan Disease and Demography," in Chinookan Peoples, 229-49; and Boyd, The Coming of the Spirit of Pestilence: Introduced Infectious Diseases and Population Decline Among Northwest Coast Indians, 1774-1874 (Seattle and Vancouver: University of Washington and UBC Presses, 1999), 231-61.

3. In the print volume an abbreviated version with a map appears in chapter 2 . See David Ellis, "Cultural Geography of the Columbia River," Chinookan Peoples, map 2.1.

4. The term Middle Chinook is from Hymes's personal communication to Zenk in about 1998. A linguistic argument for Hymes's reclassification, giving Kathlamet Chinook as the language-name, appears in Marianne Mithun, The Languages of Native North America (New York: Cambridge University Press, 1999), 382. The traditional classification appears in Laurence C. Thompson and M. Dale Kinkade, "Languages," in Handbook of North American Indians, volume 7: Northwest Coast, ed. Wayne Suttles (Washington, D.C.: Smithsonian Institution, 1990), 41.

5. Robert E. Moore, Lian Malai Madsen, and Jan Van der Aa (editor), “'Taking Up Speech' in an Endangered Language: Bilingual Discourse in a Heritage Language Classroom," Tilburg Papers in Culture Studies 69, LFR Seminar Discussion and Com- ments, https://www.tilburguniversity.edu/ upload/87b37f91-c318-463f-a39a-3bb35agfdaco_TPCS_69_Moore-etal.pdf (accessed February 8, 2016). Gladys Thompson, one of the last fluent first-language speakers of Kiksht, was instrumental in starting the language classes. She passed on in 2012, but her students continue teaching today.

6. Michael Silverstein, "Chinookans of the Lower Columbia," in Handbook of North American Indians, volume 7, 534. The eastern boundary of that compilation was shaped by the Handbook's editorially determined division between volume 7 (The Northwest) and volume 12 (The Plateau), the imposed "line" thereby assigning The Cascades to volume 12.

7. David French and Kathrine French, "Wasco, Wishram, and Cascades," in Handbook of North American Indians, volume 12: The Plateau, ed. Deward Walker (Washington, D.C.: Smithsonian Institution, 1998), 362-63.

8. Variations on the Chinookan term translated 'upstreamers' go back to the journals of Lewis and Clark; the form šaxlatkš is standardized according to that used in the latest authoritative edition of the journals. 'Downstreamers' was independently given by the Clackamas Kiksht speaker Victoria Howard, who dictated one of the principal collections of Kiksht texts, and by Marshell Martineau, a Cascades Kiksht speaker who provided village names to Edward S. Curtis's team. "Kathlamet" (we fail to find a phonetically precise spelling in this extended sense) is from Charles Cultee, who dictated Kathlamet Texts to Boas, and from Sam Millett, a Kathlamet speaker who provided lower-river village-names to the Curtis team. See Meriwether Lewis and William Clark, The Journals of the Lewis and Clark Expedition, Volume 6, ed. Gary Moulton (Lincoln: University of Nebraska Press, 1990), 10; Melville Jacobs, Clackamas Chinook field-notes, 1929-30 (field notebook 52, page 77; field 
notebook 67, page 134), Melville Jacobs Papers, University of Washington Libraries Special Collections, Seattle [herafter Melville Jacobs Papers]; Franz Boas, Kathlamet Texts, Bureau of American Ethnology Bulletin 26 (Washington, D.C.: U.S. Government Printing Office, 1901), 6. See below for discussion of the Curtis compilation.

9. Phonetic denotes the measurable features of sounds as we utter and hear them. A phoneme is a phonetic unit in a language that can convey a distinction in meaning. The sets of phonemes differ from one language to another.

10. Lewis and Clark, Journals, Volume 6, 48; and Lewis and Clark, Journals, Volume 7, 23.

11. R.B. Hinds journals, Science Collection, Mss 1524, Oregon Historical Society Research Library, Portland, Oregon, [hereafter OHS Research Library].

12. Samuel Parker, Journal of an Exploring Tour Beyond the Rocky Mountains (Minneapolis: Ross \& Haines, 1838, reprint 1967), 167.

13. The Chinookan word for 'town' or 'village' (ílxam in Kathlamet, for example) also appears in various inflected forms referring to 'people' (for example, Kathlamet tálxam 'people'). Dell Hymes, "The Language of the Kathlamet Chinook" (Ph.D. diss., Indiana University, 1955), 120. In Chinookan, by implication, people are assumed to be villagers. Chinookan tálxam is the source of Chinuk Wawa tílixam 'person, people' (also used for 'relative(s), tribes-person/people'), which has recently been honored in Tilikum Crossing, the name bestowed on the newest bridge crossing the Willamette River in downtown Portland, Oregon.

14. Lewis and Clark, Journals, Volume 6, 48; and Lewis and Clark, Journals, Volume 7, 23. Alexander Henry, The Journal of Alexander Henry the Younger, 1799-1814, Volume 2: The Saskatchewan and Columbia Rivers, ed. Barry M. Gough (Toronto: Champlain Society, 1992), 641, 677. Since Henry contrasted the "range" of houses with the eight detached structures, it seems likely that the "range" was of a kind found elsewhere in the Wapato Valley, consisting of a long stretch of connected units. In 1835 John Ball noted: "Some of these [houses] are two hundred feet in length, and a whole village live in one house." Troy Lecture, 1837, John Ball Papers, Mss 195, OHS Research Library.

15. Franz Boas, Chinook Texts, Smithsonian Institution, Bureau of American Ethnology, Bulletin 20 (1894), 222, 248-52; Verne F. Ray, "Lower Chinook Ethnographic Notes," University of Washington Publications in Anthropology 7:2 (1938), 58, 63. Concomly, for instance, was related to Kiesno, chief at Cathlacumup (village no. 30), and to the Clatsop and Chehalis chiefs, at least. Duncan McDougall, Annals of Astoria: the Headquarters Log of the Pacific Fur Company on the Columbia River, 1811-1813, ed. Robert Jones (New York: Fordham University Press, 1999), 206; Lewis and Clark, Journals, Volume 6, 17; Lewis and Clark, Journals, Volume 7, 38.

16. Lewis and Clark, Journals, Volume 6, 17.

17. Lewis and Clark, Journals, Volume 6 , 154. The rise of Concomly from a "secondary chief" in Lewis and Clark's time to the most prominent Chinook chief by 1812 resulted from his aggressive "trading" practices, as indicated in Charles Bishop's account. Charles Bishop, The Journal and Letters of Charles Bishop on the Northwest Coast of America, 1794-1799, ed. Michael Roe (Cambridge: Cambridge University Press, 1967), 118-19, 121-22.

18. Lewis and Clark, Journals, Volume 6 , 218, 221-22.

19. "The North American Indian" volumes 8 and 9, ca. 1910, in Edward S. Curtis Manuscripts: The North American Indian collection [hereafter Curtis Manuscripts], GC 1143, box 8, folder 8.15 and box 9, folder 9.1, Seaver Center for Western History Research Natural History Museum of Los Angeles County, California [hereafter Seaver Center] (see below for detail on this manuscript). While ucmuyáqxan does not meet the Chinookan Peoples of the Lower Columbia River compilers' criteria for citation as a numbered village, 
it appears in the online list in a note to village 13 (Chinook village and Chinook village cluster). On the origin of slaves, see Lewis and Clark, Journals, Volume 6, 365, 367; Ray, "Lower Chinook Ethnographic Notes," 52; George Gibbs, "Tribes of Western Washington and Northwestern Oregon," in U.S. Department of the Interior, Contributions to North American Ethnology, Volume 1 (Washington, D.C.: U.S. Government Printing Office, 1877), 189; Daniel Lee and Joseph Frost, Ten Years in Oregon (Fairfield, Wash.: Ye Galleon Press, 1968 [1844]), 103; John Scouler, "Journal of a Voyage to Northwest America," Oregon Historical Quarterly 6:2 (June 1905): 195-96.

20. George Simpson, Fur Trade and Empire: George Simpson's Journal, Frederick Merk, ed. (Cambridge: Harvard University Press, 1931), 97.

21. Ray, "Lower Chinook Ethnographic Notes," 55; Gabriel Franchere, Journal of a Voyage to the North West Coast of North America During the Years 1811, 1812, 1813, and 1814, ed. and trans. W. Kaye and Wessie Lamb (Toronto: Champlain Society, 1969), 102.

22. Lewis and Clark, Journals, Volume 6, 423-89. Regarding the fever and ague epidemics, see Boyd, "Lower Chinookan Disease and Demography," 229-49; and Boyd, The Coming of the Spirit of Pestilence, 231-61.

23. Robert Boyd and Yvonne Hajda, "Seasonal Population Movement Along the Lower Columbia River: the Social and Ecological Context," American Ethnologist 14:2 (1987): 309-26.

24. McDougall, Annals of Astoria; Alexander Kennedy, Report, Fort George District, Columbia Department, 1824-25, Ms 8.76/e, Hudson's Bay Company Archives, Winnipeg, Canada; Meredith Gairdner, "Notes on the Geography of the Columbia River," Journal of the Royal Geographic Society 11 (1841): 250-57. Only the original manuscript of Kennedy's at the Hudson's Bay Company Archives is trustworthy; that reprinted in Simpson, Fur Trade and Empire is full of errors. Regarding Michel Laframboise, see George Lang, Making Wawa: the Founding of Chinook Jargon (Vancouver: UBC Press, 2008), 56-58; Lang cites evidence that, alone among fur-company era settlers, only Laframboise achieved a measure of fluency in Chinookan (as opposed to pidgin Chinookan, that is, Chinuk Wawa).

25. Boas, Chinook Texts; Boas, Kathlamet Texts; Edward S. Curtis, The North American Indian, ed. F.W. Hodge, vols. 8, 9 (Norwood, Mass: Plimpton Press, 1970 reprint of 1911 and 1913); Ray, "Lower Chinook Ethnographic Notes," 29-165.

26. Livingston Farrand, Chinook [tribe and village names in Boas's hand], 1905 , manuscript in Records of the Bureau of American Ethnology, Series 1, Correspondence, Letters Received, 1888-1906, box 100), National Anthropological Archives, Smithsonian Institution, Washington, D.C.; Farrand, entries on Chinook, Clatsop, Kathlamet, and Wahkiakum, in Handbook of American Indians North of Mexico, ed. Frederick Hodge, 2 vols., Smithsonian Institution, Bureau of American Ethnology Bulletin 30 (Washington, D.C.: U.S. Government Printing Office, 1907-10); "The North American Indian," volumes 8 and 9, Curtis Manuscripts, Seaver Center; The Papers of John Peabody Harrington, John Peabody Harrington Collection, microfilm volume 1, reels $17,18,20$, Smithsonian Institution, available online http://anthropology.si.edu/naa/ harrington/harrington_mf1.html (accessed February 22, 2016).

27. Becky Saleeby and Richard Pettigrew, "Seasonality of Occupation of Ethnohistorically Documented Villages on the Lower Columbia River," in Prehistoric Places on the Southern Northwest Coast, ed. Robert Greengo, Thomas Burke Memorial Washington State Museum Research Report 4, Seatlle, Washington, 1983; Rick Minor, "Aboriginal Settlement and Subsistence at the Mouth of the Columbia River" (Ph.D. diss., University of Oregon, 1983); Yvonne Hajda, "Regional Social Organization in the Greater Lower Columbia, 1792-1830" (Ph.D. diss., University of Washington, 1984); Silverstein, "Chinookans of the Lower Columbia"; and French and French, "Wasco, Wishram, and Cascades."

28. Eugene S. Hunn, E. Thomas Morning Owl, Phillip E. Cash Cash, and Jennifer Karson Engum, Čáw Pawá Láakni / They Are Not Forgotten: Sahaptian Place Names Atlas 
of the Cayuse, Umatilla, and Walla Walla (Tamastslikt Cultural Institute: distributed by University of Washington Press, 2015). Two other notable sources on local place names are: an ethnogeographic text dictated in Northwest Sahaptin by Jim Yoke, published by Melville Jacobs, "Northwest Sahaptin Texts, Part 1," Columbia University Contributions to Anthropology, Volume 19, Part 1: (New York: Columbia University Press, 1934), 228-37; and Helen Norton, Robert Boyd, and Eugene Hunn's "The Klikatat Trail of South-central Washington: a Reconstruction of Seasonallyused Resource Sites," in Boyd, Indians, Fire, and the Land in the Pacific Northwest (Corvallis: Oregon State University Press, 1999).

29. Some anthropologists and linguists have tended to overlook Curtis, considering the quality of the work appearing under his name to amount to something less than real professional anthropology. Indeed, the Chinookan Peoples of the Lower Columbia chapter titled "History of Anthropological Research on Lower Chinookan Peoples" contains mention of Curtis only because Zenk took it upon himself to interpolate a one-paragraph account of the Curtis project into the late Wayne Suttles' original draft, which made no mention of it whatsoever. Wayne Suttles, "History of Anthropological Research on Lower Chinookan Peoples," Chinookan Peoples of the Lower Columbia, 326-35. The professionals' dismissal of Curtis may go all the way back to Curtis's famous contemporary, Franz Boas, the "father" of modern American anthropology. According to Mick Gidley, Edward S. Curtis and the North American Indian, Incorporated (New York: Cambridge University Press, 1998), 126: "Curtis himself, in memoirs recorded in later life, certainly felt that he was opposed by Franz Boas. . . While there is no documentary support for the existence of any particular dispute between Boas and Curtis over the anthropological authority of The North American Indian, on a couple of occasions Curtis certainly expressed suspicions of Boas to [Frederick W.] Hodge ... . and relied on Hodge's ability, revered both by Boas and his opponents, to stand above factional disputes."

30. Curtis, North American Indian, vol. 8, 180-83; Curtis, North American Indian, vol. 9, $172-73$.

31. Mick Gidley, "Edward S. Curtis and the North American Indian Project in the Field," The Annals of lowa 63 (2014), 11-12, 150.

32. Gidley, Edward S. Curtis North American Indian, Incorporated, 306; "The North American Indian," volumes 8 and 9, Curtis Manuscripts, Seaver Center. We are indebted to George Lang for arranging to have the Curtis draft village lists copied for us from the originals in the Seaver Center.

33. Thomas Smith, letter to Joel Palmer, November 25, 1855, Records of the Oregon Superintendency of Indian Affairs, microfilm held at OHS Research Library,

34. The historical recency of Sahaptin occupation along the lower Lewis River region is documented by William Tappan, Annual Report, Southern Indian District, Washington Territory, September 30, 1854, mf reel $17 \mathrm{Re}$ cords of the Washington Superintendency of Indian Affairs. See Robert Boyd, Cathlapotle and Its Inhabitants, 1792-1865, U. S. Fish and Wildlife Service Region, Cultural Resource Series no.15 (Portland, 2011), 141-46.

35. Boyd, Cathlapotle and Its Inhabitants, 14-33.

36. Boas, Handbook of American Indian Languages, Smithsonian Institution, Bureau of American Ethnology, Bulletin 40 (Washington, D.C.: U.S. Government Printing Office, 1911), 563.

37. Silverstein, "Chinookans of the Lower Columbia," 545.

38. Philip Drucker, Clackamas Upper Chinook ethnographic notes from John Wacheno, Grand Ronde, Oregon, 1934, Mss 4516 (78, 82), Philip Drucker Papers, National Anthropological Archives, Smithsonian Institution, Washington, D.C. The village name in question appears there in the spelling "q'acūx č̃x" (?q'ašúxšix).

39. Melville Jacobs, Clackamas Chinook Texts, Indiana University Research Center in Anthropology, Folklore and Linguistics Publication 8 (Bloomington, 1958-59), 462; and Jacobs, Clackamas Upper Chinook field-notes, 1928-29, field notebook no. 52, p. 10, Melville Jacobs Papers. 